\title{
Paleo sea levels reconsidered from direct observation of paleoshoreline position during Glacial Maxima (for the last 500,000 yr)
}

\author{
Marina Rabineau ${ }^{a,{ }^{*}}$, Serge Berné ${ }^{b}$, Jean-Louis Olivet ${ }^{b}$, Daniel Aslanian ${ }^{b}$, \\ François Guillocheau ${ }^{\mathrm{c}}$ and Philippe Joseph ${ }^{\mathrm{d}}$
}

\author{
a CNRS, UMR6538,Domaines Océaniques, IUEM, 29280 Plouzané, France \\ b IFREMER, DRO/GM,BP 70, 29280 Plouzané, France \\ c Géosciences Rennes, Université de Rennes 1, 35042 Rennes, France \\ d IFP, Division Géologie-Géochimie, BP311, 92506 Rueil Malmaison, France \\ *: Corresponding author : marina.rabineau@univ-brest.fr
}

\begin{abstract}
:
The drastic climatic changes which characterise the cooling trend of the last few million years of Earth history led to variations in eustatic sea level that had tremendous impact on the geology and ecology of continental margins. Reconstructing a sea-level curve back in time is not an easy task. Observations of shoreline positions are always a local measurement of Relative Sea Level that needs to be corrected from the effect of tectonic and thermal subsidence, sediment loading, compaction and glacio-hydro isostasy. Extensive studies have been done for the last deglaciation and for the last $100,000 \mathrm{yr}$ cycle. But very few studies deal with position of sea level during earlier cycles, simply because conditions are very rarely favourable for the preservation of such witnesses. The shelf of the Golfe du Lion (Western Mediterranean) reveals a unique record of shoreline paleopositions during glacial maxima of at least the last five circa $100 \mathrm{kyr}$ glacial/interglacial cycles. In fact it is the entire glacial deltaic lobe of up to $50 \mathrm{~m}$ thick (from delta front or shoreface to prodelta) that has been preserved in place and which provides direct and independent constraints for relative sea-level minima. We measure a relative sea level of: $-112 m,-128,-134,-246$ and $-262 m$ for MIS 2, 6, 8, 10 and 12 respectively. After corrections taking into account postdepositional movement of strata (subsidence), we find, that sea level dropped to a depth of $-102 \pm 6 \mathrm{~m}$ during the last three glaciations (MIS2, MIS6, MIS8) but reached exceptionally low values of more than $-150 \pm 10 \mathrm{~m}$ during the preceding glaciations MIS10 and MIS 12 at about 340 and $434 \mathrm{kyr}$ BP. This general time framework and sedimentological interpretation has been confirmed by preliminary results from two deep drillings during the PROMESS cruise (july 2004), which validate our methodology. However, no detailed and absolute datings of such witnesses are available so far, so that we cannot prove that these levels are the lowest ever reached during each glacials, but they correspond undoubtedly to the last preserved shoreface before rapid sea-level rise. We also suggest that the abrupt change in sealevel maxima might be the overprint of $400 \mathrm{kyr}$ orbital periodicity cycles. Last but not least, these results prove that the Golfe du Lion is indeed a unique laboratory to study paleoclimates and sea-level variations on a larger time scale. Further work is needed for a complete glacio-hydro-sedimento isostatic modelling of each sequence and each glacial to further constraint local sea level versus global sea level and quantify, in particular the relative effect of glacio-hydro isostatic effect (which differ according to ice sheet extend) but also of erosion-sedimentation isostatic effect (erosion on land and deposition on the outer shelf and slope).
\end{abstract}

Keywords: sea-level changes; sea-level amplitudes; glacioeustatism; shoreline position; climatic cycles; glacial maxima; subsidence; Golfe du Lion; Gulf of Lions; Mediterranean Sea 


\title{
Corrigendum to:
}

Paleo sea levels reconsidered from direct observation of paleoshoreline position during Glacial

\section{Maxima}

\section{(for the last 500,000 years)}

\author{
Marina Rabineau ${ }^{a}$, Serge Berné ${ }^{b}$, Jean-Louis Olivet ${ }^{b}$, Daniel Aslanian ${ }^{b}$, François Guillocheau', Philippe Joseph ${ }^{\text {d }}$ \\ a CNRS, UMR6538,Domaines Océaniques, IUEM, 29280 Plouzané , France \\ b IFREMER, DRO/GM,BP 70, 29280 Plouzané, France \\ c Géosciences Rennes, Université de Rennes 1, 35042 Rennes, France \\ d IFP, Division Géologie-Géochimie, BP311, 92506 Rueil Malmaison, France
}

In the above article, some typing errors have occured for the values of $\mathrm{W}_{\mathrm{e}}$ and $\mathrm{W}_{\mathrm{s}}$.in Table 2 .

The correct Table 2 is given below with its updated Table caption (corrected values are shown in red).

Av. : average value between the two measurements

In the legend, the correct formula to calculate $\mathrm{Wm}$ is $\mathrm{W}_{\mathrm{m}}=\left(\mathrm{W}_{\mathrm{e}} \times 0,75\right)+\left(\left(\mathrm{W}_{\mathrm{s}}-\mathrm{W}_{\mathrm{e}}\right) \times 0,8\right)$

We also added an uncertainty in our measurement of top shoreline depth on seismic ( $2 \mathrm{~ms})$

Overall, final results are not changed, the uncertainty asssociated to the value is a little higher $(2 \mathrm{~m})$.

Authors would like to apologize for any inconvienience caused. 


\begin{tabular}{|c|c|c|c|c|c|c|c|c|c|c|c|c|c|}
\hline 1 & 2 & 3 & 4 & 5 & 6 & 7 & 8 & 9 & 10 & 11 & 12 & 13 & 14 \\
\hline$D_{i}$ & MIS & $\begin{array}{c}\mathrm{D} \\
(\mathrm{km})\end{array}$ & $\begin{array}{l}\mathrm{W}_{\mathrm{e}} \\
(\mathrm{ms})\end{array}$ & $\begin{array}{c}\mathrm{W}_{\mathrm{s}} \\
(\mathrm{ms}) \\
\text { on Profile } \\
\end{array}$ & $\begin{array}{l}\mathrm{W}_{\mathrm{m}} \\
(\mathrm{m})\end{array}$ & $\begin{array}{l}\mathrm{b} \\
(\mathrm{m})\end{array}$ & $\begin{array}{l}\text { RSL } \\
\text { (m) }\end{array}$ & $\begin{array}{l}\text { RSL } \\
(\mathrm{m})\end{array}$ & $\begin{array}{c}\mathrm{R} \\
(\mathrm{m} / \mathrm{Ma})\end{array}$ & $\begin{array}{l}\mathrm{A} \\
(\mathrm{ka})\end{array}$ & $\begin{array}{l}\mathrm{S} \\
(\mathrm{m})\end{array}$ & $\begin{array}{l}\text { CSL } \\
(\mathrm{m})\end{array}$ & $\begin{array}{c}\text { CSL } \\
\text { CSL(m) }\end{array}$ \\
\hline D70 & Stage 2.2 & 69 & 150 & $\begin{array}{l}150 \text { P1055+/-2 } \\
150-\mathrm{P} 1047+/-2\end{array}$ & $112+/-2$ & $0-10$ & $\begin{array}{c}-102-112+/- \\
2\end{array}$ & $-\mathbf{1 0 7}+/-7$ & $245+/-10$ & $20+/-5$ & $5+/-1$ & $(97)-107+/-3$ & $-102+/-8$ \\
\hline D60 & Stage 6.2 & 66 & $\begin{array}{l}157 \\
140\end{array}$ & $\begin{array}{l}168 \text { P1052+/-2 } \\
170 \text { P1046+/-2 }\end{array}$ & $\begin{array}{c}\text { Av. } \\
128+/-2\end{array}$ & $0-10$ & $\begin{array}{c}-118-128+/- \\
2\end{array}$ & $-123+/-7$ & $232+/-9$ & $135+/-5$ & $31+/-2$ & $(85)-97+/-5$ & $-92+/-9$ \\
\hline$\overline{\mathrm{D} 50}$ & Stage 8.02 & 53 & 122 & $175-\mathrm{P} 1046+/-2$ & $134+/-2$ & $0-10$ & \begin{tabular}{|c|}
$-124-134+/-$ \\
2 \\
\end{tabular} & $-\mathbf{1 2 9}+/-7$ & $175+/-7$ & $247,6+/-5$ & $43+/-3$ & $(81)-91+/-5$ & $-\mathbf{8 6}+/-10$ \\
\hline $\mathrm{D} 40$ & Stage10.2 & 74 & 272 & $325-P 1036+/-2$ & $246+/-2$ & $0-10$ & \begin{tabular}{|c|}
$-236-246+/-$ \\
2 \\
\end{tabular} & $-241+/-7$ & $267+/-10$ & $341+/-5$ & $91+/-5$ & $(145)-155+/-7$ & $-\mathbf{1 5 0}+/-11$ \\
\hline D30 & Stage 12.2 & 70 & 207 & $341-\mathrm{P} 1036+/-2$ & $262+/-2$ & $0-10$ & \begin{tabular}{|c|}
$-252-262+/-$ \\
2
\end{tabular} & $-257+/-7$ & $250+/-10$ & $434+/-5$ & $108+/-5$ & $(144)-154+/-7$ & $-\mathbf{1 4 9}+/-12$ \\
\hline
\end{tabular}

Updated Table 2

Estimate of Corrected Sea Level (CSL) from the depth of successive shorelines and subsidence corrections. Column 1: $\mathrm{D}_{\mathrm{i}}$ Erosional surface names as interpreted from seismic profiles; $[60,54]$. Column 2: MIS: Marine Isotope Stage. Column 3: D (km): distance from the present day coast as measured along the profile. Column $4: \mathrm{W}_{\mathrm{e}}$ : Water-column height above shorelines (in ms twtt). Column 5: $\mathrm{W}_{\mathrm{s}}$ top shoreline depth below present sea level is measured on seismic profiles $\mathrm{P}$ (in milliseconds two way travel time) with an uncertainty of $2 \mathrm{~ms}$ Column 6: $\mathrm{W}_{\mathrm{m}} \mathrm{Top}$ shoreline depth below present sea level calculation in meters, considering a velocity in water $\mathrm{V} 1=1500 \mathrm{~m} / \mathrm{s}$ and in the sediments $\mathrm{V} 2=1600 \mathrm{~m} / \mathrm{s}$. $\mathrm{W}_{\mathrm{m}}=\left(\mathrm{W}_{\mathrm{e}} \times 0,75\right)+\left(\left(\mathrm{W}_{\mathrm{s}}-\mathrm{W}_{\mathrm{e}}\right) \times 0,8\right)$. Av. : average value using the two measurements of $\mathrm{W}_{\mathrm{s}}$

Column 7: $b$ Paleobathymetry $(\mathrm{m})$ and uncertainty associated. Column 8 and 9: RSL Relative Sea Level calculation (below present sea-level). Column 10: R: Subsidence rate that varies as a function of the tilt of the margin (from $0 \mathrm{~m} / \mathrm{Myr}$ at $13 \mathrm{~km}$ to $250 \mathrm{~m} / \mathrm{Myr}(+/-10 \mathrm{~m} / \mathrm{Myr}$ ) at $70 \mathrm{~km}$ from present day coast). The rate is constant through time but varies according to the position along the profile: $\mathrm{R}(\mathrm{m} / \mathrm{Myr})=(\mathrm{D}-13) * 250 /(70-$ 13). The uncertainty reflects the uncertainty in the calculation. Column 11: A: Age of deposit is taken from dated isotope stages as defined on the SPECMAP curve and is associated with an average error of $5 \mathrm{kyr}$ [73]; [80]. Column 12: S: The amount of subsidence (tilt) is calculated from subsidence rate and the age of the deposit (the associated error is related to errors on the age and on the subsidence). Corrected sea level (CSL) (column 13 and 14) is calculated from the shoreface depth W (m) (column 6) minus the amount of subsidence (column 12) minus a correction for paleobathymetry estimates: b (column 7). 


\section{Introduction}

Throughout the Quaternary, sea level evolution is directly linked to climate variations and the induced throb of ice sheets. During the last decades, extensive efforts have been made to obtain a subcontinuous record of paleoclimatic changes from the study of marine, continental or ice cores with, in particular, great progress in the use of isotopic ratios. However, such data do not give direct access to sea level history. A simple linear relationship between the oxygen isotope record and global continental ice volume [1] or a more elaborate relationship [2] is often taken as a first approximation but is known to be too simplistic [3] [1] [2]. Direct proofs of sea level position such as morphologic, diagenetic or organic features (e.g. marine notches, terraces, archeological data, beach rocks, peats or coral constructions...) can be obtained from geological evidence on continental margins to calibrate the curves. But sea level obtained in that way is a local Relative Sea level (RSL) as the Earth surface is subject to subsidence or uplift. This Relative Sea level needs to be corrected from the effects of tectonic and thermal subsidence, sediment loading and compaction, glacio-hydro isostasy, gravitational potential, in order to obtain a Corrected Sea level (CSL). To do so with confidence, the geological context of the studied area needs to be chosen carefully and known in great detail. In any case, neither of these two approaches alone (isotopic and geological) is sufficient to reconstruct a continuous calibrated sea level curve; we need to compare and combine their results. This has been done successfully for the last deglaciation (from 20 to 0 cal-kyr BP) using corals, dating methods $\left({ }^{14} \mathrm{C}\right.$ and $\mathrm{U} / \mathrm{Th}$ ) [4] [5] [6] [7] [8] [9], glacio-hydro-isostatic models [10] [11] [12] or hydraulic model of water exchange [13]. Few studies also tried to calibrate the last interglacial and the entire last glacial cycle (OIS 5 to OIS 3) in the same way using corals and dating methods [5] [14] [15] [16] [17] [18] [19] [20] [21] but also stalagmites, speleothems and dating methods [22] [23] or again using glacio-hydrostatic models [24] [25] [26]. However, the comparaison of all these studies show that even the sea level at the Last Glacial Maximum (LGM) is still not so well constrained and that discrepancies subsist between estimates (table 1 and Fig. 1). On a longer time scale, apart from the original study of Rohling [27] using variations in salinity in the Red Sea as observed in cores and related to sea-level variations for the last 500,000 years and the following work of Siddall using hydraulic 
modelling in the Red Sea [13], and the new long drillings in reefs [28], there have been very few studies using direct geological field evidence to estimate quantitative paleo-sea level amplitudes, especially for low stands and earlier glacials (table 1). The work of Ferland [29] is one of the few attempts based on sediment cores on the shelf. The present work provides new estimates of Corrected sea-level amplitude for the last five glacials on the outer shelf of the Golfe du Lion, Western Mediterranean Sea.

\section{Method: using seismic images to measure sea-level amplitude}

Many factors of global, regional or local scale have long been recognised to control the overall geometry and deposition of sediments. Seismic stratigraphy was developped at the end of the 70's, to address part of those questions that were critical for petroleum exploration [30] but this type of work deals with long-term evolution of sea-level with sequences of the order of $1 \mathrm{Ma}$.

. At the end of the 80 's Sequence Stratigraphy developed with a conceptual model that linked the formation of sequences and their resulting geometries to a cycle of variation of relative sea-level (RSL) (e.g. : [31, 32] [33]). This work in turn led to the well-known "eustatic chart of Haq et al. [34] [35] with a revision from Hardenbol et al., [36]. However, it has to be noted that this work deals with long-term evolution of sea-level with sequences of the order of $1 \mathrm{Ma}$.

On shorter time scales, (i.e. Pleistocene), many studies have also been undertaken on continental margins. They are too numerous to be cited. However, we note that, to our knowledge, very few attempts have been made to use these observations to estimate sea-level. This was also partly due to the inability to drill in shallow water, that has long hampered progress in reconstructing sea level history [37]. So, in most studies paleoclimatic curves derived from isotopic data were used as a reference and sequences observed on the field were correlated directly to the paleoclimatic curves (e.g. [38] [39]). One attempt of amplitude determination after the work of [40] [41] was proposed by Skene using numerical stratigraphic modelling [42] that led him to a modification of sea-level curves (see his curve in Fig. 1). 
Our study gives an estimate of relative sea-level magnitudes during the last five glacial maxima from unique direct seismic observation of delta front using high quality and very high resolution Sparker Seismic data acquired in a unique geological context: the Golfe du Lion (see details in section 3 and 4.).

\section{Studied site: The Golfe du Lion, an unique site to study sea level variations}

The Golfe du Lion offers a perfect natural laboratory for sea level calibration of glacial maxima for the climatic cycles during Plio-Pleistocene (Fig. 2) as: (a) the Mediterranean Sea has been connected to the global ocean throughout Plio-Quaternary time, so that sea level variations are directly linked to Arctic and Antarctic ice caps fluctuations (b) The Golfe du Lion is a young margin resulting from the rotation of the Corso-Sardinian block between about $21 \mathrm{Myr}$ and 15 Myr [43] [44]. The subsidence is still underway at present and continually creates a large amount of space to be filled by sediments (i.e. an accommodation); (c) During the Last Glacial Maximum, mountain glaciers covered a large part of the Alps, and there were smaller glaciers in the Pyrenees and the Massif Central. However, neither the drainage basins nor the shelf were covered by ice (Fig. 2-B). Moreover, the Golfe $d u$ Lion is situated sufficiently far from former ice sheets (hundreds of kilometers) for important glacio-isostasy of the margin to be excluded, so that sea-level follows, in a first approximation, the eustatic changes (Cit.[45], p.204); (d) The mountain glaciers did not significantly impact on global sea level but their presence led to important erosion and scouring providing an important source of sandy sediments, to be transported by rivers and ultimately deposited in the Golfe du Lion; (e) The western part of the Gulf, on which we will focus our study, is not under the direct influence of deposits coming from the Rhone (Fig. 2-C and Fig. 3); the reduced sediment input, together with a wide shelf (up to $70 \mathrm{~km}$ ) and ongoing subsidence, favoured a progressive filling of the available space, and therefore the recording of the comings and goings of shorelines, and the rise and fall of sea levels.

As a result, previous attempts have been successfully undertaken to estimate LGM sea level and Deglacial sea-level curves in the Golfe du Lion and nearby, using shallow core data [46], [47], [48] and glacio-hydro isostatic modelling: during LGM, sea levels along the coast and immediate off-shore 
areas stood at between $105-115 m$ below present sea-level [45]. The glaciohydro isostatic signals in this region, at LGM, are of the order of $10-15 \%$ of the eustatic contribution and vary significantly across the shelf because of the water loading.

So far, no estimates were available in the Golfe $d u$ Lion for earlier cycles and earlier glacial maxima.

\section{Defining Paleoshoreline positions through time and duration of sequences}

The recent compilation of bathymetric data [49] shows that the continental shelf comprises three main areas (Fig. 2-C and 2-D and Fig. 3).

(a) On the inner part, between the present coast $0 \mathrm{~m}$ and isobath $90 \mathrm{~m}$ (around 30 $\mathrm{km}$ seaward of the coast), bathymetric contour lines indicate a step from 0-10 m corresponding to present day prism PII (shoreface sandy deposits), then smooth contour lines with bulges related to the subaqueous part (prodeltas) of transgressive and high stand deltaic lobes that have been mapped, sampled and dated (post $18 \mathrm{kyr}-\mathrm{C} 14)([46],[50],[51],[52])$.

(b) On the outer part, between 90 and $100 \mathrm{~m}$, bathymetric contour lines indicate a very flat area with smaller scale rough morphology. A distinct notch or step occurs at the end of this area at $110 \mathrm{~m}$ (Fig. 3). Shallow cores (few meters long) indicate that sediments outcropping (from 90 to $110 \mathrm{~m}$ ) are sands [53] (see also figure 2 in [54]).

(c) Between 120 and $160 \mathrm{~m}$, isobaths are smooth again on interfluves with silty to muddy prodeltaic offshore deposits.

The compilation and 3D analysis of Very High Resolution seismic data (Sparker and 2,5 $\mathrm{kHz}$ data) combined with the analysis of shallow cores, shows that the sedimentation repeats through time with a distinct sedimentary motif PI/PII/(PIII) developed between major erosion surfaces D30, D40, D50, D60 and D70 [54] (Fig. 4-A and B). Five sequences S1, S2, S3, S4 and S5 are therefore stacked vertically and separated by the erosion surfaces, clearly identifiable on seismic profiles. 
Evidence integrating lithology, palynology, micropaleontology, from 21 cores sampling the last sequence S5 with 14 radiocarbon datings together with seismic stratigraphy and numerical stratigraphic modelling demonstrate that the top of PII-t2, which corresponds to the step observed on the outer shelf (Fig. 3) represents the preserved position of the delta front/shoreface during the LGM and that the outcome motif preserved on the outer shelf is the result of one 100,000 years climatic cycle [54].

$\mathrm{S5}$ is the result of deposition/erosion throughout a cycle of variation of sea-level (MIS3/MIS2/MIS1) as summarised on Fig. 4-B. MIS5 was deposited during the high stand on the inner shelf (as in present day conditions), and eroded during following sea level lowering. PI-t1 was deposited during MIS3, (Core VK-20 shows a prodeltaic, upper offshore paleoenvironment (Ostracodes (mostly infralittoral species, 60m water depth) dated at 45 cal-kyr BP, steppic pollens and Dinokystes of cold period). PII-t2 and PI-t2 are deposited during MIS2: paleoenvironments of PI-t2 in C12 are shallow (30-40 $\mathrm{m}$ according to Pteropodes and Foraminifera) and dated at 23,1 cal-kyr BP, Paleoenvironment of PII-t2 is very shallow (delta frontupper shoreface $(5-10 \mathrm{~m}$ water depth) with in some places the formation of beachrocks at the top ( $0 \mathrm{~m}$ water depth) dated between 21 cal-kyr and 15,5 cal-kyr [55], [56]. PIII-t3 is very limited in thickness, it takes the form of reworking sand dunes that are deposited during MIS1 (C9 shows both cold and warm Foraminifera, dated at $\mathbf{1 4 , 1 3 9}$ cal-kyr). A Full description of this data set is published in Rabineau et al., (2005). More detailed work has also been undertaken for the transgressive dunes [57] and the last sequence [56].

The geometry of this area represents the ancestral landscape as it stood some 20 thousand years ago (during MIS2) with little reworking during the subsequent rapid transgression [58] [59]. We showed [60] [54] that the motif PI/PII/(PIII) is complete, only, in the western part of the Gulf (around the Aude-Hérault canyons). Towards the East (the Rhône) and to the South (Cap Creus) PII is often missing (not deposited or eroded). 
In depth, seismic profiles show a total of five sequences of prisms PI/PII/(PIII)(S1 to S5), separated by major erosional surfaces: D30, D40, D50, D60, D70 (Fig.3 and 4). Each prism PII corresponds to the deposition and preservation of the shorelineshoreface of glacial times. The preservation of the shoreline-shoreface is not the same everywhere, i.e. erosion occurs (subaerial and submarine) (Fig 5). So, defining the zone where shoreline is the most well preserved needs a detailed 3D interpretation of all seismic lines. This has been done in great detail in the Aude-Hérault area with detailed maps of all units and surfaces [59], [60] [54]. This work enables us to map the shoreline at the time of glacial maxima and to define the bestly preserved outer limit of best preserved glacial delta front as seen on seismic profiles (Fig. 5) and mapped in 3D (Fig. 6).

We tested the hypothesis that each of the sequences was being deposited during a cycle of the same order of magnitude and duration as S5, i.e.: 100000 years. This hypothesis effectively enabled us to reproduce correct geometries using numerical stratigraphic modelling [60] [54]. So the last 5 erosion surfaces and preserved delta front-shoreface correspond to delta front related to MIS2, MIS6, MIS8, MIS10 and MIS12.

Preliminary results from two deep drillings realised during the PROMESS cruise (july 2004) confirm the overall chronostratigraphic framework for the last 500,000 years (originally based on seismic stratigraphy interpretation and numerical stratigraphic modelling): "The occurrence of Pseudoemiliana lacunosa below 270 mbsf indicates that Marine isotope stage MIS 12 was reached at the bottom of the hole GL1 on the upper slope " [Promess cruise Newsletter 3], [61] which $\begin{array}{llllllll}\text { corresponds } & \text { to } & \text { D } 30 & \text { at } & \text { the } & \text { top } & \text { of } & \text { S1 }\end{array}$ (http://www.pangaea.de/Projects/PROMESS1/Cruise)

The preservation of such paleoshorelines-shoreface through successive glacial/interglacials is unique (a clear position of the shoreline was not the case for Skene et al., 1998 for example, or in Adriatic where there is very little sands): our quantification is the first and enables a quantification of sea-level amplitude because we really can "see" the shoreface (or the delta front) preserved at each glacials. 


\section{Defining "total Subsidence"}

Previous studies in the area have shown that tectonic subsidence associated with rifting was small and that most of the subsidence, which takes the form of a seaward tilting of the shelf, only started in Miocene time as a consequence of postrift thermic cooling enhanced by sediment loading [62] [63]. This subsidence effect is clearly shown on seismic profiles where erosion surfaces, which represent the same environment at different times, show angles of inclination that increase with age (with depth below earth surface) (Fig. 7). The present day depth of paleoshorelines therefore corresponds to the depth below SL at time of deposition plus the movement of the floor after deposition. Here we can measure the tilting on the seismic profiles by the inclination of successive erosion surfaces (Fig. 7). This analysis has been done at the Plioquaternary scale (for the last 5,3 Ma) using a dense grid of industrial petroleum seismic data and industrial drillings that give access to paleobathymetries and thicknesses of deposits through time. The seismic shows that our studied area (in the languedocian region) subsided regularly without substantial local deformation; this enables us to propose a model for the subsidence with a linear tilt. The rate increases with the distance from the Coast, it reaches a rate of $250 \mathrm{~m} / \mathrm{Ma}$ at $70 \mathrm{~km}$ from the coast, for the last 5,3 $\mathrm{Ma}$ [60].

Of course, an uncertainty is associated with the estimate of subsidence, corresponding to errors in the measurements, time-depth conversion, paleomorphology variations, and the linear interpolation. We estimated this error to $\pm 10 \mathrm{~m} / \mathrm{Ma}$.

This "total" subsidence measured from a geometrical point of view is the overall outcome of any processes by which the ground surface has moved on average at the margin scale.

\section{From RSL to CSL at successive glacial maxima}

The measurement of Relative Sea Level (RSL) from our data can be done relative to present day Sea Level $(\mathrm{t}=0)$. It is defined as the difference between present depth $\mathrm{W}_{(0)}$ and paleowaterdepth of the soil (b) at time of deposition t. $\mathrm{RSL}_{(\mathrm{t})}=\mathrm{W}_{(0)}-\mathrm{b}_{(\mathrm{t})}$, (figure 
3B). Paleobathymetry $b_{(t)}$ is not an easy parameter to define in sediments, it is usually estimated from cores with a description and evolution of sedimentary facies with microfossil asssemblages defining open marine, shallow marine, marginal marine and brackish environment e.g. [29], [11], [64]. In the western part of the Golfe du Lion, seismic data images directly provide the position of the delta front at glacial maximum (prism PII) and its present day depth $\mathrm{W}_{(0)}$. This point has been taken on the most seaward position of prism PII, where it has last been deposited and most well preserved, i.e. near the Hérault $\mathrm{H} 1$ and $\mathrm{H} 2$ canyon heads (Fig. 5 and Fig. 6). This position corresponds to the mouth of the paleoriver feeding and building this lobe (the MIS2 shelf edge delta lobe) (Fig. 3 and Fig. 5). This last lobe is the most well preserved and has not been eroded afterwards, as pictured on the seismic images (Fig. 4 and Fig. 5). Therefore, at that point, the paleo-waterdepth $\mathrm{b}$ is equal to 0 (with an uncertainty of $10 \mathrm{~m}$; i.e. $b=5+/-5 \mathrm{~m})$, we measure a water depth of $112 \mathrm{~m}$.

So, $\operatorname{RSL}_{(\mathrm{LGM})}=\mathrm{W}_{(0)}-\mathrm{b}_{(\mathrm{LGM})}=112-5=107+/-5 \mathrm{~m}$.

As paleoshoreface (or delta front) are all recorded in this area of the Golfe du Lion, and as we interpreted seismic lines in $3 \mathrm{D}$, we are able to define the point where the shoreline is most well preserved and therefore to calculate RSL during glacial maxima related to MIS 6,8,10 and 12 (Fig. 5 and table 2). But those measurements need to be corrected from the effect of subsidence. CSL $=$ RSL $-\mathrm{S}$, where $\mathrm{S}=$ Total Subsidence.

At $69 \mathrm{~km}$ from the present coast, total subsidence rate is $245+/-10 \mathrm{~m} / \mathrm{Myr}$ (see section 5 and table 2 for details). For MIS 2 (20 calendar-ka); this tilt reaches $5+/-1 \mathrm{~m}$. Thus, corrected sea level at isotope stage 2.2 (LGM) is

$\mathrm{CSL}_{(\mathrm{LGM})}=102+/-6 m$. at MIS 2.2

This value is consistent with previous estimates in the region based on molluscs ages [46], [47], [48] and also based on glacio-hydro isostatic modelling: during LGM, sea levels along the coast and immediate off-shore areas stood 
at between 105-115m below present sea-level [45]. More recent studies suggested a RSL of at least $-115 \mathrm{~m}$ [56] but this value is not corrected from subsidence of the shelf.

The question, now, is whether or not our measured and corrected sea-level corresponds to the global value of sea-level? As noted in Lambeck and Bard, the isostatic correction is of the order of 10-15 $\mathrm{m}$ so that the Global glacio-hydroisostatically corrected value would be about 112-117 \pm 7 or 8 , which is not very different from that found elsewhere. However, part of this isostatic correction due to the water loading, is compensated by the sediment loading at the same time. During LGM, sea-level is about -100-120 $\mathbf{m}$ below present, this creates a deficit in water loading on the shelf. But, at the same time, sediment has also been deposited on the outer shelf, on the slope and in the deep sea (see thickness of S5, about $30 \mathrm{~m}$, on figure 4 and 5 for example); these deposits induce an extra loading that could well compensate the water-loading deficit (as density of sediment is higher than density of water). This calculation ought to be modelled in details in the near future, also taking into account the timing of events (deposition versus sea level drop).

As calculated for stage 2, we defined the Corrected Local position of sea level during successive glacial maxima MIS12, MIS10, MIS8 and MIS 6 that give respective values of 149, 150, 86, and $92 \mathrm{~m}$ (see table 2 and Fig. 5 and Fig. 8). Glacio-hydro-sediment isostatic corrections should also be done. They will not be the same for each glacial maximum and will depend on the location of ice margins, on the sea level itself, and on the quantity of sediment eroded and deposited.

\section{Paleoclimatic implications}

If our model of subsidence is correct, our results show that:

(1) Corrected sea level at LGM fell to $-102+/-6 \mathrm{~m}$ on the outer shelf of the Golfe $\mathrm{du}$ Lion during MIS2. The CLIMAP project provided two possible scenarii for ice sheet extent and volumes [65] a minimum scenario with restricted ice sheets leading to a LGM of $-127 \mathrm{~m}$ and a maximum scenario with expanded marine ice-sheets 
accounting for $-163 \mathrm{~m}$ of sea-level lowering. Clark et al. [66], in an introduction to a recent issue of QSR, dedicated to the results of the EPILOG project [66] [67], concluded that even though the now well-constrained ice-sheet extent was near the maximum scenario of CLIMAP, sea level at the LGM was only between -120 and $135 \mathrm{~m}$. Our study, based on paleoshorelines, suggests that this value is still overestimated. However our estimate is still local and no isostatic corrections were applied. Previous estimates for sea level position at the LGM were very weakly constrained by direct observations and were often dependent on strong assumptions inherent to indirect methods. The studies on corals, that have proven to be very efficient for the last deglaciation, present only two measures for the LGM: $-118 \mathrm{~m}$ [6] and >-125m [8] (Table 1 and Fig. 1). The latter value could be decreased by an amount of $20 \mathrm{~m}$ (and therefore be $-105 \mathrm{~m}$ ), because the Porites corals seem to be able to live down to $20 \mathrm{~m}$ [68]. A recent study on the Sunda shelf [64] gives a value of $-116 \mathrm{~m}$ (at $21 \mathrm{ka}$ ) but as stated by the authors it is "poorly defined". Rohling also found a value of $-120 \mathrm{~m}$ but his estimation is dependent on the a priori that sea level was $-125 \mathrm{~m}$ at MIS-6. Combining the large ice sheet extent (near the maximum CLIMAP value) and our value for lowstand sealevel for the LGM, would imply that ice sheets were therefore much thinner than presently assumed. One could also argue that the observed shoreface does not correspond to the lowest sea-level during MIS2. It is true that no detailed and absolute datation of such shoreface is available so far, so that we do not prove that these levels are the lowest ever reached during each glacials. However, we do not observe shoreface at lower depth on the shelf.

(2) Corrected sea level during MIS6 on the outer shelf of the Golfe du Lion, is also much higher, $-92+/-7 \mathrm{~m}$, than usually assumed (around $\mathbf{- 1 2 5 m}$ ). In fact, sea level during MIS 6 is even more poorly constrained; most studies are indirect, mainly based on oxygen isotopic data, which are not a direct function of sea level [69] [1]. The study from Ferland et al., gives a sea-level drop to a depth less than $125 \mathrm{~m}$ because cores showed no evidence of subaerial erosion. No glacio-hydro isostatic modelling has ever been undertaken for MIS6, the ice volume of the Eurasian ice sheet may have been larger than during stage 2, this isostatic contribution may also well have been larger and the calculation needs to be done. 
(3) Our local sea level measurement on the outer shelf of the Golfe du Lion, imply important differences in sea level minima: MIS 2, 6, 8 are of the same magnitude and the lowstands dropped to a much lower value during MIS 10 and 12. This abrupt change occurs around 350-kyr and we suggest that it could be related (together with the change in cycles duration and magnitude at $800-\mathrm{kyr}$ ) to the $400 \mathrm{kyr}$ cycles associated with the excentricity of the Earth that have surprisingly rarely been observed in most paleoclimatic records [70].

(4) At MIS 10 and 12, sea level dropped to $-150+/-9$ and $-149+/-10 \mathrm{~m}$ respectively. Rohling [27] using a very different and original method (extreme high-salinity conditions recorded in cores from the Red Sea) also found greater glaciations during MIS 10 and 12 (table 2). Not taking into account the absolute value (based on the $a$ priori that SL was -125 at MIS6), Rohling found glaciations $15 \mathrm{~m}$ greater during MIS10 and 12 compared to MIS6 (Fig. 8). Our lowstand estimates reflect much more extreme glaciations during MIS 10 and MIS12 (60 m greater) than MIS6. Previous studies always concluded that MIS 12 is more intense than stage 10. Here, we found the same order of magnitude. One could argue that the sequence deposited during MIS 10 was totally eroded, implying a misdating of the oldest two sequences which would then be older. However, this hypothesis would require an especially intense glaciation during MIS 8 in order to erode a complete sequence, for which there is no present evidence (see Fig. 5C for exemple where sequences are fully preserved on the upper slope at the location of GL1 PROMESS core).

\section{Conclusions}

Knowledge of glacio-eustatic changes is essential for the estimation of ice volumes, for a better understanding of the rates and amplitudes of glacial build-up and decay.

Direct field evidence gathered in the Golfe $d u$ Lion, gives a geological validation of 100,000 years glacial-interglacial cycles, which are recorded by the progradationretrogradation of the shoreline as a consequence of sea level fluctuations. The record and preservation of paleoshorelines and shorefaces on the outer shelf corrected from the model of subsidence of the margin allows the assessment of sea level lowering during successive glaciations. We conclude that glaciations were much milder during MIS 8, 6, 
2, with a drop of sea level smaller than previously published estimates; on the contrary, glaciations during MIS 10 and MIS 12 with a sea level a drop of sea level much higher than previously published estimates. These results are conditioned by our global model for subsidence. As no detailed and absolute datations of such shorefaces are available so far, we can not prove that these levels are the lowest ever reached during each glacials.

We also suggest that the abrupt change in these extreme glaciations recorded in the sedimentary pattern of the Golfe $d u$ Lion may mark the imprint of 400,000 year cycles associated with orbital excentricity [70]. We further raise the question : could the transition from 40,000 to 100,000 years cycles that occurred around 800 kyr have the same origin? Further attention needs to be drawn to the 400,000 years cycle and its consequences on the Earth's climate.

The preliminary results of the very recent drilling PROMESS seem to be in agreement with all our results and validate our methodology. They also show that all sequences are preserved in the Golfe du Lion. Such a record is outstanding on continental margins, the Golfe $d u$ Lion is therefore an unique Laboratory to study sea level in relation to paleoclimates, because of a subtle and rare combination of factors (shelf width, high subsidence rate, sandy sediment flow but lower than in front of the Rhône, moderate wave energy, no tides). In our study, only the uppermost part of the sedimentary column in the Golfe du Lion has been studied in detail. Deeper sediments need to be explored and dated for sea-level research in order to test and extend our results further back in time and to investigate important events such as the onset of Northern Hemisphere glaciations (around 2,6 Ma). Our results provide a step towards using sea-level minima from continental margin sediment patterns to calibrate oxygen isotope data for the entire Plioquaternary.

We insist on the need to take into account subsidence effect (s.1.), which is important even in this tectonically stable passive margin and relatively short time intervals (500,000 years). If the subsidence did not exist, sequences would not be preserved, erosion during successive lowstands would completely erase previously deposited sequences (as this is the case on the shelf of the Bay of Biscay margins during 
Quaternary for example). This is the reason why this place, the Golfe du Lion, is unique. Preservation of sequences is only due to subsidence. Preservation of glacial shoreface is also due to the rapid rise in sea level after deposition. These observation and results ought to be used for a detailed "glacio-hydro-sedimento" isostatic modelling of each sequence and each glacial to further constraint local sea-level versus global sea-levels, and quantify, in particular the relative effect of glacio-hydro isostatic effect (which differ according to ice sheet extend) but also of erosion-sedimentation isostatic effect (erosion on land and deposition on the outer shelf and slope).

Acknowledgements: The final manuscript greatly benefited from the comments and advices of Kurt Lambeck. We thank David Needham for fruitful discussions and a critical review of the manuscript. Didier Granjeon for guidance and help on stratigraphic simulation. M. Rotuno, T. Marsset, G. Lericolais, J-F. Bourillet, J-L Rubino, F. Trincardi, for useful discussions at an early stage of this work; D. Paillard, E. Michel and C. Waelbroeck for advice on the manuscript and data on isotopic curves. E. Ledrezen for her long-term assistance. J. Baztan, C. Gorini, M. Gaudin, G. Jouet for later discussion on the topic. David Needham and Barbara Harris for their final review as English native speakers. This research was mainly funded by IFREMER and CNRS. Additional support comes from IFP (Christian Ravenne, Rémi Eschard), the French GDR Marges (French "Margins" programme) and from the European Community through the Eurostrataform (EVK3-CT-2002-00079) and Promess 1 (EVR1-CT-2002-40024) projects. This is contribution XX to IUEM publication and contribution YY of French “GDR Marges” program. 


\section{References}

[1] N.J. Shackleton, Oxygen Isotopes, Ice Volume and Sea level, Quaternary Science Review 6 (1987) 183-190.

[2] C. Waelbroeck, L.D. Labeyrie, E. Michel, J.-C. Duplessy, J. McManus, K. Lambeck, E. Balbon and M. Labracherie, Sea level and deep water changes derived from benthic Foraminifera isotopic record, Quaternary Science Review 21(1-3) (2002) 295-305.

[3] A.C. Mix and W.F. Ruddiman, Oxygen-isotope analyses and Pleistocene ice volumes, Quaternary Research 21(1) (1984) 1-20.

[4] R.G. Fairbanks, A 17,000-year glacio-eustatic sea level record: influence of glacial melting ates on the Younger Dryas event and deep-ocean circulation, Nature 342 (1989) 637-642.

[5] E. Bard, B. Hamelin and R.G. Fairbanks, U-Th ages obtained by mass spectrometry in corals from Barbados: sea level during the past 130,000 years, Nature 346 (1990) 456-458.

[6] E. Bard, B. Hamelin, M. Arnold, L. Montaggioni, G. Cabioch, G. Faure and F. Rougerie, Deglacial sea-level record form Tahiti corals and the timing of global meltwater discharge, Nature 382 (1996) 241-244.

[7] J. Chappell, A. Omura, T. Esat, M. McCulloch, J. Pandolfi, Y. Ota and B. Pillans, Reconciliation of late Quaternary sea levels derived from coral terraces at Huon Peninsula with deep sea oxygen isotope records, Earth and Planetary Science Letters 141 (1996) 227-236.

[8] E. Bard, M. Arnold, B. Hamelin, N. Tisnerat-Laborde and G. Cabioch, Radiocarbon calibration by means of mass spectrometric 230Th/234U and 14C ages of corals. An updated data base including samples from Barbados, Mururoa and Tahiti., Radiocarbon 40(3) (1998) 1085-1092.

[9] G.F. Camoin, L.F. Montaggioni and C.J.R. Braithwaite, Late glacial to post glacial sea levels in the Western Indian Ocean, Marine Geology 206(1_4) (2004) 119-146.

[10] K. Lambeck, Sea-level change along the French Atlantic and Channel coasts since the time of the Last Glacial Maximum, Palaeogeography, Palaeoclimatology, Palaeoecology 129 (1997) 1-22.

[11] Y. Yokoyama, K. Lambeck, D.D. P., P. Johnston and L.K. Fifield, Timing of the Last Glacial Maximum from observed sea-level minima, Nature 406 (2000) 713716.

[12] Y. Yokoyama, K. Lambeck, P. De Deckker, P. Johnston and L.K. Fifield, Timing of the Last Glacial Maximum from observed sea-level minima: Correction, Nature 412 (2001) 99.

[13] M. Siddall, R. E.J., A. Almogi-Labin, C. Hemleben, D. Meischner, I. Schmelzer and D.A. Smeed, Sea-level fluctuations during the last glacial cycle, Nature 423 (2003) 853-858.

[14] M. Stein, G.J. Wasserburg, P. Aharon, J.H. Chen, Z.R. Zhu, A. Bloom and J. Chappell, TIMS U-series dating and stable isotopes of the Last Interglacial event in Papua New Guinea, Geochim. Cosmochim. Acta 57 (1993) 2541-2554.

[15] Z.R. Zhu, K.-H. Wyrwoll, L.B. Collins, J.H. Chen, G.J. Wasserburg and A. Eisenhauer, High-precision U-series dating of Last Interglacial events by mass 
spectrometry: Houtman Abrolhos Islands, western Australia, Earth and Planetary Science Letters 118(1-4) (1993) 281-293.

[16] C.D. Gallup, R.L. Edwards and R.G. Johnston, The timing of high sea levels over the past 200,000 years, Science 263 (1994) 796-800.

[17] B.J. Szabo, K.R. Ludwig, D.R. Muhs and K.R. Simmons, Thorium-230 ages of corals and duration of the last interglacial sea-level high standon Oahu, Hawaii, Science 266 (1994) 93-96.

[18] C.H. Stirling, T.M. Esat, M.T. McCulloch and K. Lambeck, High-precision Useries dating of corals from western Australia and implications for the timing and duration of the Last Interglacial, Earth and Planetary Science Letters 135 (1995) 115-130.

[19] M.A. Toscano and J. Lundberg, Submerged Late Pleistocene reefs on the tectonically-stable S.E. Florida margin: high precision geochronology, stratigraphy, resolution of Substage 5a sea-level elevation, and orbital forcing, Quaternary Science Reviews 18 (1999) 753-767.

[20] J. Chappell, Sea level changes force by ice breakouts in the Last Glacial cycle: new results from coral terraces, Quaternary Science Review 21 (2002) 12291240.

[21] K.B. Cutler, R.L. Edwards, F.W. Taylor, H. Cheng, J. Adkins, C.D. Gallup, P.M. Cutler, G.S. Burr and A.L. Bloom, Rapid sea-level fall and deep-ocean temperature change since the last interglacial period, Earth and Planetary Sciance Letters 206 (2003) 253-271.

[22] E. Bard, F. Antonioli and S. Silenzi, Sea-level during the penultimate interglacial period based on submerged stalagmite from Argentarola Cave (Italy), Earth and Planetary Sciance Letters 196(3-4) (2002) 135-146.

[23] F. Antonioli, E. Bard, E.-K. Potter, S. Silenzi and S. Improta, 215-ka History of sea-level oscillations from marine and continental layers in Argentarola Cave Speleothems (Italy), Global and Planetary Change 43 (2004) 57-78.

[24] Y. Yokoyama, T.M. Esat and K. Lambeck, Coupled climate and sea-level changes deduced from Huon Peninsula, Papua New Guinea, Earth and Planetary Science Letters 193 (2001) 579-587.

[25] Y. Yokoyama, T.M. Esat and K. Lambeck, Last Glacial sea-level change deduced from uplifted coral terraces of Huon Peninsula, Papua New Guinea, Quaternary International 83-85 (2001) 275-283.

[26] K. Lambeck and J. Chappell, Sea level change through the Last Glacial Cycle, Science 292 (2001) 679-686.

[27] E.J. Rohling, M. Fenton, F.J. Jorissen, P. Bertrand, G. Ganssen and J.P. Caulet, Magnitudes of sea level lowstands of past 500,000 years, Nature 394 (1998) 162-165.

[28] G.F. Camoin, P. Ebren, A. Eisenhauer, E. Bard and G. Faure, A 300,000-yr coral reef record of sea-level changes, Mururoa atoll (Tuamotu archipelago, French Polynesia), Palaeogeography, Palaeoclimatology, Palaeoecology 175 (2001) 325-341.

[29] M. Ferland, P. Roy and C. Murray-Wallace, Glacial Lowstand Deposits on the Outer Continental Shelf of Southeastern Australia, Quaternary Research 44 (1995) 294-299.

[30] C.E. Payton, Seismic stratigraphy - applications to hydrocarbon exploitation, Amer. Assoc. Petroleum Geol. Memoir 26, Tulsa, Oklahoma, (1977). 516 pp. 
[31] H.W. Posamentier, M.T. Jervey and P.R. Vail, Eustatic controls on clastic deposition I. Conceptual framework, in: Sea-Level Changes- an Integrated Approach, C.K. Wilgus, B.S. Hastings, C.G.S.C. Kendall, H.W. Posamentier, C.A. Ross and J.C. Van Wagoner, eds. (1988a) pp. 102-124, SEPM Spec. Pub. 42, Tulsa.

[32] H.W. Posamentier and P.R. Vail, Eustatic controls on clastic deposition II. Sequences and system tract models, in: Sea-Level Changes- an Integrated Approach, C.K. Wilgus, B.S. Hastings, C.G.S.C. Kendall, H.W. Posamentier, C.A. Ross and J.C. Van Wagoner, eds. (1988b) pp. 125-154, SEPM Spec. Pub. 42, Tulsa.

[33] P.R. Vail, J.P. Colin, R.J. Du Chene, J. Kuchly, F. Mediavilla and V. Trifilieff, La stratigraphie séquentielle et son application aux corrélations chronostratigraphiques dans le Jurassique du Bassin de Paris, Bull. Soc. Géol. France 8(7) (1987) 1301-1321.

[34] B.U. Haq, J. Hardenbol and P. Vail, Chronology of fluctuating sea levels since the Triassic (250 million years ago to present), Science 235 (1987) 1156-1167.

[35] B.U. Haq, J. Hardenbol and P. Vail, Mesozoic and Cenozoic chronostratigraphy and cycles of sea-level change, SEPM special publication 42 (1988) 71-108.

[36] J. Hardenbol, J. Thierry, M.B. Farley, P.-C. de Graciansky and P.R. Vail, Mesozoic and Cenozoic Sequence Chronostratigraphic Framework of European basins, in: Mesozoic and Cenozoic Sequence Stratigraphy of European basins, P.-C. de Graciansky, J. Hardenbol, T. Jacquin and P.R.E. Vail, eds. 60 (1998) pp. 3-13, Charts 11-18, SEPM, special publication.

[37] IODP-IPSC, Earth, Oceans and Life. Scientific Investigation of the Earth System Using Multiple Drilling Platforms and New Technologies, (2001). 110 pp.

[38] J. Torres, B. Savoye and P. Cochonat, The effects of Late Quaternary sea-level changes on the Rhône slope sedimentation (northwestern Mediterranean), as indicated by seismic stratigraphy, Journal of Sedimentary Research B65(3) (1995b) 368-387.

[39] F. Trincardi and A. Correggiari, Quaternary forced-regression deposits in the Adriatic Basin and the record of composite sea-level cycles, in: Sedimentary responses to forced regressions, D. Hunt and R. Gawthorpe, eds. 134 (2000) pp., Geological Society Special Publication, London.

[40] A.E. Aksu, T.J. Calon, D.J.W. Piper, S. Turgut and E. Izdar, Architecture of late orogenic Quaternary basins in the northeastern Mediterranean Sea, Tectonics 210 (1992) 191-213.

[41] J.A. Berry and D.J.W. Piper, Seismic stratigraphy of the Scotia Rise: record of continental margin glaciation, Geo-Marine Letters 13 (1993) 197-206.

[42] K.I. Skene, D.J.W. Piper, A.E. Aksu and J.P.M. Syvitski, Evaluation of the global oxygen isotope curve as a proxy for Quaternary sea level by modeling of delta progradation, Journal of Sedimentary Research 68(6) (1998) 1077-1092.

[43] J.L. Olivet, La cinematique de la plaque Iberique $\mid$ O Kinematics of the Iberian Plate, Bulletin des Centres de Recherches Exploration-Production Elf-Aquitaine 20(1) (1996) 131-195.

[44] F. Speranza, I.M. Villa, L. Sagnotti, F. Florindo, D. Cosentino, P. Cipollari and M. Matei, Age of the Corsica-Sardinia rotation and Liguro-Provencal Basin 
spreading: new paleomagnetic and Ar/Ar evidence, Tectonophysics 347(4) (2002) 231-251.

[45] K. Lambeck and E. Bard, Sea-level change along the French Mediterranean coast fro the past 30000 years, Earth and Planetary Science Letters 175 (2000) 203-222.

[46] J.C. Aloïsi, A. Monaco, J. Thommeret and Y. Thommeret, Evolution paléogéographique du plateau continental languedocien dans le cadre du golfe du Lion; Analyse comparée des données sismiques, sédimentologiques et radiométriques concernant le Quaternaire récent, Revue de Geographie Physique et de Geologie Dynamique 17(1) (1975c) 13-22.

[47] J. Labeyrie, C. Lalou, A. Monaco and J. Thommeret, Chronologie des niveaux eustatiques sur la côte du Roussillon de -33000 ans B.P. à nos jours, Comptes Rendus de l'Académie des Sciences de Paris 282 (1976) 349-352.

[48] J.C. Aloïsi, Sea level variations on the french Mediterranean margin during the Holocene, Paleoclimate Research; Paläklimaforshung nºspec. (1993) 25 p..

[49] S. Berné, D. Carré, B. Loubrieu, J.-P. Mazé and A. Normand, Carte morphobathymétrique du Golfe du Lion à l' échelle 1/100 000 ème (2001) pp., IFREMER et Région Languedoc Roussillon, Brest.

[50] B. Gensous, D. Williamson and M. Tesson, Late-Quaternary transgressive and highstand deposits of a deltaic shelf (Rhône delta, France), in: Sequence stratigraphy and facies associations, H.W. Posamentier, C.P. Summerhayes, B.A. Haq and G.P. Allen, eds. (1993b) pp. 197-212, International Association of Sedimentologists Spec. Pub. 18, Blackwell, Oxford.

[51] T. Marsset and V. Bellec, Late Pleistocene-Holocene deposits of the Rhône inner continental shelf (France): detailed mapping and correlation with previous continental and marine studies, Sedimentology 49 (2002) 255-276.

[52] S. Berné, J.C. Aloïsi, J. Baztan, B. Dennielou, L. Droz, T. Dos Reis, J. Lofi, Y. Méar and M. Rabineau, Notice de la carte morpho-bathymétrique du Golfe du Lion 1 (2002) pp. 48, IFREMER et Région Languedoc Roussillon, Brest.

[53] J.C. Aloïsi, H. Got, A. Monaco and C. Duboul-Razavet, Carte géologique du précontinent pyrénéo-languedocien au 1/250 000 (1973) pp., Musée Océanographique de Monaco.

[54] M. Rabineau, S. Berne, D. Aslanian, J.-L. Olivet, P. Joseph, F. Guillocheau, J.F. Bourillet, E. Ledrezen and D. Granjeon, Sedimentary sequences in the Gulf of Lion: A record of 100,000 years climatic cycles, Marine and Petroleum Geology 22(6-7) (2005) 775-804.

[55] P. Bernier, Les Pierres de Sète : un indicateur paléobathymétrique et paléoenvironnemental, in: Atelier Golfe du Lion du GDR Marges (2000) pp., Paris.

[56] G. Jouet, S. Berné, M. Rabineau, M.-A. Bassetti, P. Bernier, B. Dennielou, Flores-Jose-Abel, Sierro-Francisco-Javier and M. Taviani, Shoreface migrations at the shelf edge and sea-level changes around the Last Glacial Maximum (Gulf of Lions, NW Mediterranean), Marine Geology (in press).

[57] M.-A. Bassetti, G. Jouet, F. Dufois, S. Berné, M. Rabineau and M. Taviani, Deglacial sedimentary processes and deposits in the outer continental shelf of the Gulf of Lions (western Mediterranean), Marine Geology (in press).

[58] S. Berné, G. Lericolais, T. Marsset, J.F. Bourillet and M. de Batist, Erosional offshore sand ridges and lowstand shorefaces: examples from tide and wave 
dominated environments of France, Journal of Sedimentary Research 68(4) (1998b) 540-555.

[59] M. Rabineau, S. Berné, E. Ledrezen, G. Lericolais, T. Marsset and M. Rotunno, 3D architecture of lowstand and transgressive Quaternary sand bodies on the outer shelf of the Gulf of Lion, France, Marine and Petroleum Geology 15(5) (1998) 439-452.

[60] M. Rabineau, Un modèle géométrique et stratigraphique des séquences de dépôts quaternaires de la plate-forme du Golfe du Lion : enregistrement des cycles glacioeustatiques de 100000 ans, Thèse de Doctorat, Université de Rennes 1, IFREMER and IFP, (2001), (392 + 370) p. (392 vols), http://www.ifremer.fr/docelec

[61] Colmenero-Hidalgo-Elena, Gravalosa-Jose, Flores-Jose-Abel, Sierro-FranciscoJavier, Berne-Serge, Canals-Miquel, Cattaneo-Antonio, Floch-Gilbert, Dennielou-Bernard, Frigola-Jaume, Gelfort-Ralf, Ridente-Domenico, Schoolmeester-Tina, Sultan-Nabil, Tulloch-Graham and Wallrabe-Adams-HansJoachim, PROMESS 1 preliminary results; new high resolution coccolithophore records for the last half million years., Journal of Nannoplankton Research 26(2) (2004) Pages 22.

[62] B. De Voogd, R. Nicolich, J.L. Olivet, F. Fanucci, J. Burrus, A. Mauffret, G. Pascal, A. Argnani, J.M. Auzende, M. Bernabini, C. Bois, L. Carmignani, A. Fabbri, I. Finetti, A. Galdeano, C.Y. Gorini, P. Labaume, D. Lajat, P. Patriat, B. Pinet, J. Ravat, F. Ricci Lucchi and S. Vernassa, First deep seismic reflection transect from the Gulf of Lions to Sardinia (ECORS-CROP profiles in Western Mediterranean), in: Continental Lithosphere: Deep seismic reflections, R. Meissner, ed., Geodynamic Series 22 (1991) pp. 265-274, American Geophysical Union.

[63] C. Gorini, A. Mauffret, P. Guennoc and A. Le Marrec, Structure of the Gulf of Lions (Northwestern Mediterranean Sea), in: Hydrocarbon and Petroleum Geology of France, A. Mascle, ed. (1994) pp. 223-243, Springer-Verlag, Berlin.

[64] T. Hanebuth, K. Stattegger and P.M. Grootes, Rapid Flooding of the Sunda Shelf: a Late-Glacial Sea-Level Record, Science 288 (2000) 1033-1035.

[65] P.M. CLIMAP, Seasonal reconstruction of the earth's surface at the last glacial maximum, Geological Society of America Map and chart series 36 (1981).

[66] P.U. Clark, A.C. Mix and E. Bard, Ice sheets and sea level of the Last Glacial Maximum, EOS Transactions (2001) 241-246-247.

[67] A.C. Mix, E. Bard and R. Schneider, Environmental processes of the ice age: land, oceans, glaciers (EPILOG), Quaternary Science Review 20 (2001) 627657.

[68] Y. Yokoyama, P. De Deckker, K. Lambeck, P. Johnston and L.K. Fifield, Sealevel at Last Glacial Maximum: evidence from northwestern Australia to constrain ice volumes for oxygen isotope stage 2, Palaeogeography, Palaeoclimatology, Palaeoecology 165 (2001a) 281-297.

[69] J. Chappell and N.J. Shackleton, Oxygen isotopes and sea level, Nature 324(6093) (1986) 137-140.

[70] D. Paillard, Glacial cycles: toward a new paradigm, Reviews of Geophysics 39(3) (2001) 325-346.

[71] L.D. Labeyrie, Variations in mode of formation and temperature of oceanic deep waters over the past 125,000 years, Nature 327(6122) (1987) 477-482. 
[72] N.J. Shackleton, The 100,000-year Ice-Age cycle found to lag temperature, carbon dioxide, and orbital eccentricity, Science 289 (2000) 1897-1902.

[73] J. Imbrie, J.D. Hays, D.G. Martinson, A. McIntyre, A.C. Mix, J.J. Morley, N.G. Pisias, W.L. Prell and N.J. Shackleton, The orbital theory of Pleistocene climate: support from a revised chronology of the marine $\delta \mathrm{O}^{18}$ record, in: Milankovitch and climate, A. Berger, Imbrie, J., Hays, J., Kukla, G., Saltzman, B., ed., Series C: Mathematical and Physical Sciences 126 (1984) pp. 269-305, Kluwer Academic Publishers, Hingham, Mass.

[74] Bassinot F., Labeyrie L., Vincent E., Quidelleur X., Shackleton N. J. and Lancelot Y., The astronomical theory of climate and the age of the BrunhesMatuyama magnetic reversal, Earth Planet. Sci. Lett. 126 (1994) 91-108..

[75] J. Ehlers, Quaternary and glacial geology, (1996). 578 pp.

[76] E. Chapron, Contrôle climatique et sismo-tectonique de la sédimentation lacustre dans l'avant-pays alpin (Lac du Bourget) durant le Quaternaire récent, (1999). $261 \mathrm{pp}$.

[77] P. Antoine, J.L. De Beaulieu, P. Bintz, J.P. Brugal, M. Girard, J.L. Guadelli, M.T. Morzadec-Kerfourn, J. Renault-Miskovsky, A. Roblin-Jouve, B. Schmider, B. Van Vliet-Lanoe and J.D. Vigne, La france pendant les deux derniers extrêmes climatiques, variabilité naturelle des environnements., (1999). 59 pp.

[78] B. Gensous, M. Tesson and M. Arnold, Analyse en stratigraphie séquentielle des dépôts pléistocènes de la plateforme orientale du Rhône (France): confrontation de l'analyse sismique et des données de terrain, C. R. Acad. Sci. Paris 317 (1993a) 803-810.

[79] S. Berné, B. Loubrieu and a.t.C.s. party, Canyons et processus sédimentaires récents sur la marge du Golfe du Lion occidental. Premiers résultats de la compagne CALMAR. Canyons and recent sedimentary processes on the western Gulf of Lions margin. First results of the Calmar cruise., Comptes Rendus de l'Académie des Sciences de Paris 328 (1999) 471-477.

[80] D.G. Martinson, N.G. Pisias, J.D. Hays, J. Imbrie, T.C. Moore, Jr. and N.J. Shackleton, Age dating and the orbital theory of the ice ages: development of a high-resolution 0 to 300,000-year chronostratigraphy, Quaternary Research 27 (1987) 1-29.

[81] T. Hughes, G.H. Denton and M.G. Grosswald, Was there a late Würm Artic ice sheet ?, Nature 266(5603) (1977) 596-602.

[82] K. Lambeck, Y. Yokoyama and A. Purcell, Into and out of the Last Glacial Maximum: sea-level change during the Oxygen Isotope 3 and 2, Quaternary Science Review 21 (2002a) 343-360.

[83] K. Fleming, P. Johnston, D. Zwartz, Y. Yokoyama, K. Lambeck and J. Chappell, Refining the eustatic sea-level curve since the Last Glacial Maximum using far-and intermediate-field sites, Earth and Planetary Science Letters 163 (1998) 327-342.

[84] W.R. Peltier, Ice age paleotopography, Science 265 (1994) 195-201.

[85] W.R. Peltier, On eustatic sea level history: last Glacial Maximum to Holocene., Quaternary Science Reviews 2 (2002b) 377-396.

[86] W.R. Peltier, Comments on the paper of Yokoyama et al. (2000), entitled "Timing

of the Last Glacial Maximum from observed sea level minima', Quaternary Science Review 21 (2002a) 409-414. 
[87] G.A. Milne, J.X. Mitrovica and D.P. Schrag, Estimating past continental ice volume from sea-level data, Quaternary Science Review 21 (2002) 361-376.

[88] I. Shennan and G.A. Milne, Sea-level observations around the Last Glacial Maximum from the Bonaparte Gulf, NW Australia, Quaternary Science Reviews 22 (2003) 1543-1547. 


\section{Figure Captions}

Figure 1 Synthesis of Sea level data (from isotopic curves, [4], [5], [71], [2], [72], [73], [74] glacioisostatic modelling [26], stratigraphic modelling [42], or punctual measurements (corals, spéléothems, salinities...). Crosses are sea level estimates for the last glacial-interglacial cycle based on U-Th dated coral reefs and other evidence (full references in Waelbroeck [2]), other punctual measurements ([27], [69], [19], [21]. Scale on right axis: variations in mean ocean water $\delta^{18} \mathrm{O}$ derived from atmospheric $\delta^{18} \mathrm{O}$. Scale on left axis (RSL) for punctual measurements. Note the differences and the uncertainties associated with the different curves and measurements for sea level estimates.

Figure 2 Location and bathymetry of the Golfe $d u$ Lion. A) Location of the Golfe $d u$ Lion within the Mediterranean Sea. B) The Golfe du Lion with its present day simplified drainage basins (mainly the Rhone to the North, the pyreneolanguedocian rivers to the West) delimited by thick red lines. In white: average and simplified maximum extension of the mountainous glaciers during last glacial maximum (LGM) (drawn and simplified using data from [75], [76] and [77]). The dotted white line shows the extension of the alpine glaciers during the penultimate Riss glaciation (MIS 6). C) Detailed bathymetric map (modified from Berné et al. [49]. A: Aude (or Bourcart) canyon; H: Hérault canyon. Note the three distinct morphologic areas from coast to shelf break and slope: (a) an area coloured in orange on the inner shelf (between the present coast and isobath $90 \mathrm{~m}$ ) (around $30 \mathrm{~km}$ seaward of the coast) with smooth bathymetric contours and a regular dip with an average slope of $0.3-0.45 \%$ (i.e. $0.17-0.25^{\circ}$ ). The deposits there correspond to post $18 \mathrm{kyr}-{ }^{14} \mathrm{C}$ sediments [46]; [47]; [78]; (b) a very flat area on the outer shelf (depth 90-100 m, width 20 to $40 \mathrm{~km}$ ) coloured in yellow with rough isobaths and a very low angle of slope $0.05-0.25 \%\left(0,015-0,03^{\circ}\right)$. At the end of $(b)$, a clear step occurs at a depth of about $112 \mathrm{~m}$ (in the western area of the gulf) and reaches dips of $4^{\circ}$. Surficial cores (several meters) indicate that sediments outcropping between $98-112 \mathrm{~m}$ 
are sand deposits (black dots in figure 2); (c) an area coloured in blue with steeper slopes and smooth isobaths, between 120 and $160 \mathrm{~m}$ on interfluves (with slopes around $0,4 \%)$. The black line represents the location of seismic profile interpreted in D). D) Profile from present day Coast (with present day sandy yellow prism PII), to the outer shelf (with regressive sandy yellow prism PII from MIS2). Note the three areas (a), (b), and (c) previously described. Grey deposits correspond to transgressive and high stand deposits (post $18 \mathrm{kyr}-{ }^{14} \mathrm{C}$ ).

Figure 3 Detailed bathymetry of the study zone on the outer shelf in the area of the Aude-Hérault canyons (modified from Berné et al. [49]). A2: head 2 of the Aude canyon ; H1 to H4: heads of the Herault canyons (nomenclature from Berné et al[79]. Crosses represent core samples, crosses with circles represent cores with datings (core numbers in red). The black line represents the location of the seismic profile shown in figure 3. Black dots on orange and yellow colours represent the extension of sandy littoral deposits of Last Glacial Maximum (MIS 2).

Figure 4 A) Seismic profile (vertical cross section) through the outer shelf in the western area of the Golfe du Lion (see position on figure 2). Vertical scale is two way travel time in milliseconds (left axis) and depth in meters (right axis). Black rectangles represent core positions with their names. Three kinds of seismic facies have been identified: in blue, low angle clinoforms made up of silts and clays (PI); in yellow, high angle clinoforms made up of sands (PII); in green dunes made up of reworked sand (PIII). The paired prisms PI-PII+(PIII)(blue-orange+green) form a sedimentary motif that repeats itself [54]. On the profile in A) three sequences (S3 to S5) are clearly identified. (the sandy prisms of Sequences S1 and S2, not visible on this profile, are on the Aude-Hérault interfluve area). V.E: vertical exaggeration (ratio betwen vertical and horizontal scale). Conversions to meters assume sound velocity of $1500 \mathrm{~m} / \mathrm{s}$ in water and $1600 \mathrm{~m} / \mathrm{s}$ in sediments. Dotted black line is the multiple. B) Formation of the 
sedimentary motif throughout a cycle of sea-level variations. The Sea-level curve is derived from Labeyrie, 1987 [71]. Black rectangles represent core positions with their names and red stars represent key cores with datings (red stars, ages in cal kyr as published in Rabineau et al., 2005). At 11 (MIS3) the shoreline is on the middle shelf of the Gulf, the depositional profile of deltaï sediments consists of a sandy prism PII (the shoreline) that evolves seaward to a silty prism PI (offshore deposits), both deposited during $\mathrm{t} 1$ and therefore called PII-t1 and PI-t1. Sea-level drops during MIS2 ( $\mathrm{t} 2)$, and induces intense erosion on the shelf that completely erases prism PII-t1, further on the outer shelf a new prism PII-t2 and PI-t2 is deposited. Sea-level rises rapidly during MIS1 (t3), and reworks previously deposited sediments on top of PI-t1 and PIIt2. So, the final sedimentary motif preserved is a triplet PI/PII/PIII capped by a major erosional surface (in red). Note, that PIII is often absent in older sequences, because of erosion during subsequent lowering of sea level in the next sequence. This scenario has been fully described in Rabineau et al., 2005, using evidence from lithology, palynology, micropaleontology, radiocarbon datings from 21 cores sampling the last sequence S5 together with seismic stratigraphy and numerical stratigraphic modelling core analysis

Figure 5: Seismic profiles (vertical cross sections) (A) $\mathrm{P} \_1052$; (B) $\mathrm{P} \_1055$ and (C) P_1036 through the outer shelf in the western area of the Golfe du Lion (see position on figure 3). Vertical scale is two way travel time in milliseconds (left axis) and depth in meters (right axis) (A) and (B) are at the same scale ; the scale in (C) is twice as small (but same vertical exaggeration). Conversions to meters assume sound velocity of 1500 $\mathrm{m} / \mathrm{s}$ in water and $1600 \mathrm{~m} / \mathrm{s}$ in sediments. Three kinds of seismic facies have been identified: in blue, low angle clinoforms made up of silts and clays (PI); in yellow, high angle clinoforms made up of sands (PII); in green dunes made up of reworked sand 
(PIII). The paired prisms PI-PII+(PIII)(blue-orange+green) form the sedimentary motif that repeats itself. The Major discontinuities are in red between sequences.

On the profile in A) two sequences (S4 and S5) are clearly identified with the paired prisms PI-PII (blue-orange). But prism PII of S5 and prism PII of S4 have different geometries. Prism PII of S5 is less than $10 \mathrm{~m}$ thick on its outer limit and this step is not so steep. We interpret this geometry as due to erosion of PII in this area (probably submarine erosion during transgression). On the contrary, PII of S4 is thick (reaching $40 \mathrm{~m}$ ) with a very steep step and very well defined and preserved sigmoïde shape. Here, prism PII has not been eroded.

On the profile in B) the five sequences are identified. In this area, prism PII of S5 is very well preserved from erosion, its top and outer limit represents the Coast at LGM (bathymetry $=0$ ), it lies at $-112 \mathrm{~m}$ below present day sea level $(\mathrm{RSL}=-112 \mathrm{~m})$.

On the profile in C) the two first sequences S1 and S2 are identified. The interfluve Aude-Hérault is the only place where they can be observed in this area.

Figure 6. 3D Mapping of the most seaward limits (maximum progradation) of prisms PII associated to the last five major 100,000 years cycles (S1 to S5, MIS12 to MIS2). The location of the area is the same as Figure 3. The limits correspond to the maximum progradation of preserved shoreface during glacials. The black dots represent the most well preserved shoreline where measurements of RSL and CSL have been performed (see Table 2) ( $\mathrm{t} 1$ to $\mathrm{t} 5$ refers to the time of deposition of $\mathrm{S} 1$ to S5. $\mathrm{t} 1(\mathrm{D} 30)=434 \mathrm{ka}, \mathrm{t} 2$ $(D 40)=341 \mathrm{ka}, \mathrm{t} 3(\mathrm{D} 50)=248, \mathrm{t} 4(\mathrm{D} 60)=135, \mathrm{t} 5(\mathrm{D} 70)=20 \mathrm{cal}-\mathrm{age}$ in ka. Age of deposit is taken from the interpretation of Rabineau, [60] and [54] the ages are from isotope stages as defined on the SPECMAP curve [73]; [80]. 
Note the absolute necessity to do a 3D analysis of seimic data, as the prisms are not all visible on one single profile. Dotted lines correspond to a zone were the prism PII is eroded at the top.

Figure 7 A) Line drawing of a seismic profile from present day coast to the outer shelf with a preservation of LGM shoreline position. The location of the profile is drawn on figure 1. The profile shows several erosional surfaces (in red) and preserved paleoshoreface (prisms PII, in yellow). Sediments stack vertically thanks to the tilt of the margin as imaged by the increasing angles of erosional surfaces. Black dots represent the preserved position of delta front (or top of shoreface) B) Sketch showing the effect of total subsidence (S) and the relation between measured Relative Sea Level (RSL) and Corrected Sea Level (CSL) after corrections from subsidence.

Figure 8 Sea level curves and geological calibration. Composite sea level curve (SL) in grey with maximum variability interval (grey zone) derived from isotopic records as shown in figure 1. Empty circles: sea level low stands estimated by Rohling [27]. Red filled circles: estimated sea level low stands from this study.

\section{Table Captions}

Table 1: Synthesis of results for the estimation of Sea level at glacial maxima during LGM, MIS 6 to MIS12 from litterature using different methods. Note the discrepencies in the results. References (as appearing in column 5) [65] [81] [26] [82] [83] [84] [85] [86] [87] [45] [28] [9] [4] [5] [64] [11] [68] [88] [69] [27]. 
Table 2 Estimate of Corrected Sea Level (CSL) from the depth of successive shorelines and subsidence corrections. Column 1: $\mathrm{D}_{\mathrm{i}}$ Erosional surface names as interpreted from seismic profiles [60]; [54]. Column 2: MIS: Marine Isotope Stage (column1). Column 3: $\mathrm{D}(\mathrm{km})$ : distance from the present day coast as measured along the profile. Column 4 : $\mathrm{W}_{\mathrm{e}}$ : Water-column height above shorelines (in $\mathrm{ms}$ twtt) and column 5: top shoreline depth below present sea level is measured on seismic profiles (in milliseconds two way travel time). Column 6: $\mathrm{W}_{\mathrm{s}}$ depth of shoreline below sea floor as measured on seismic profiles $\mathrm{P}$ (in $\mathrm{ms}$ twtt). Column 7: Top shoreline depth below present sea level calculation in meters, considering a velocity in water $\mathrm{V} 1=1500 \mathrm{~m} / \mathrm{s}$ and in the sediments $\mathrm{V} 2=1600 \mathrm{~m} / \mathrm{s} . \mathrm{W}_{\mathrm{m}}=\left(\mathrm{W}_{\mathrm{e}} \times 0,75\right)+\left(\mathrm{W}_{\mathrm{s}} \times 0,8\right) .($ Column 8: BU Paleobathymetry $(\mathrm{m})$ and uncertainty in measurement. Column 9: RSL Relative Sea Level calculation. Column 10: R: Subsidence rate that varies as a function of the tilt of the margin (from $0 \mathrm{~m} / \mathrm{Myr}$ at $13 \mathrm{~km}$ to $250 \mathrm{~m} / \mathrm{Myr}(+/-10 \mathrm{~m} / \mathrm{Myr})$ at $70 \mathrm{~km}$ from present day coast). The rate is constant through time but varies according to the position along the profile: $\mathrm{R}(\mathrm{m} / \mathrm{Myr}$ ) $=(\mathrm{D}-13) * 250 /(70-13)$. The uncertainty reflects the uncertainty in the calculation. Column 11: A: Age of deposit is taken from dated isotope stages as defined on the SPECMAP curve and is associated with an average error of 5 kyr [73]; [80]. Column 12: $\mathrm{S}$ : The amount of subsidence (tilt) is calculated from subsidence rate and the age of the deposit (the associated error is related to errors on the age and on the subsidence). Corrected sea level (CSL) (column 13) is calculated from the shoreface depth W (m) (column 7) minus the amount of subsidence (column 12) minus a correction for paleobathymetry estimates: b (column 8$)$. 


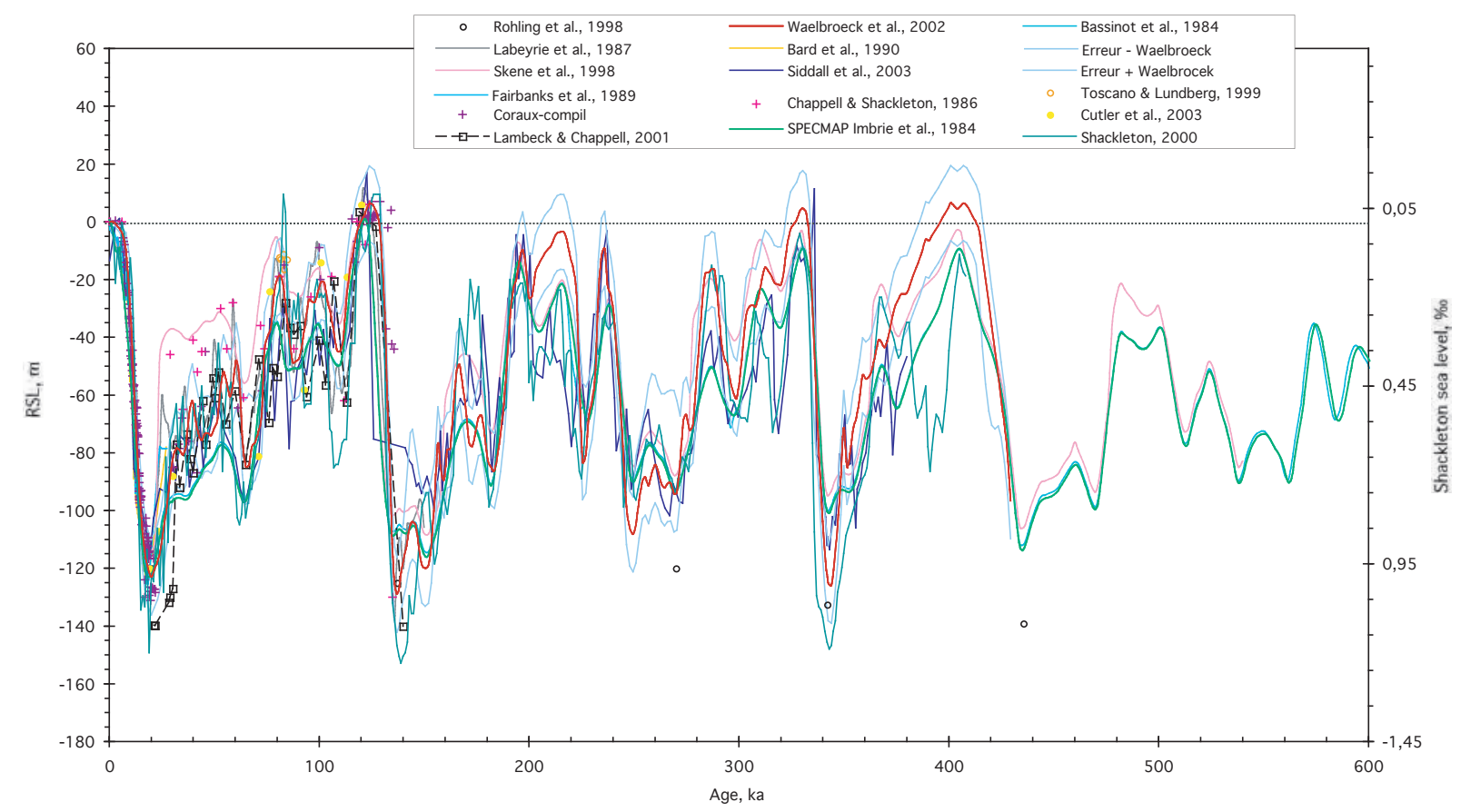

Rabineau et al., Figure 1 

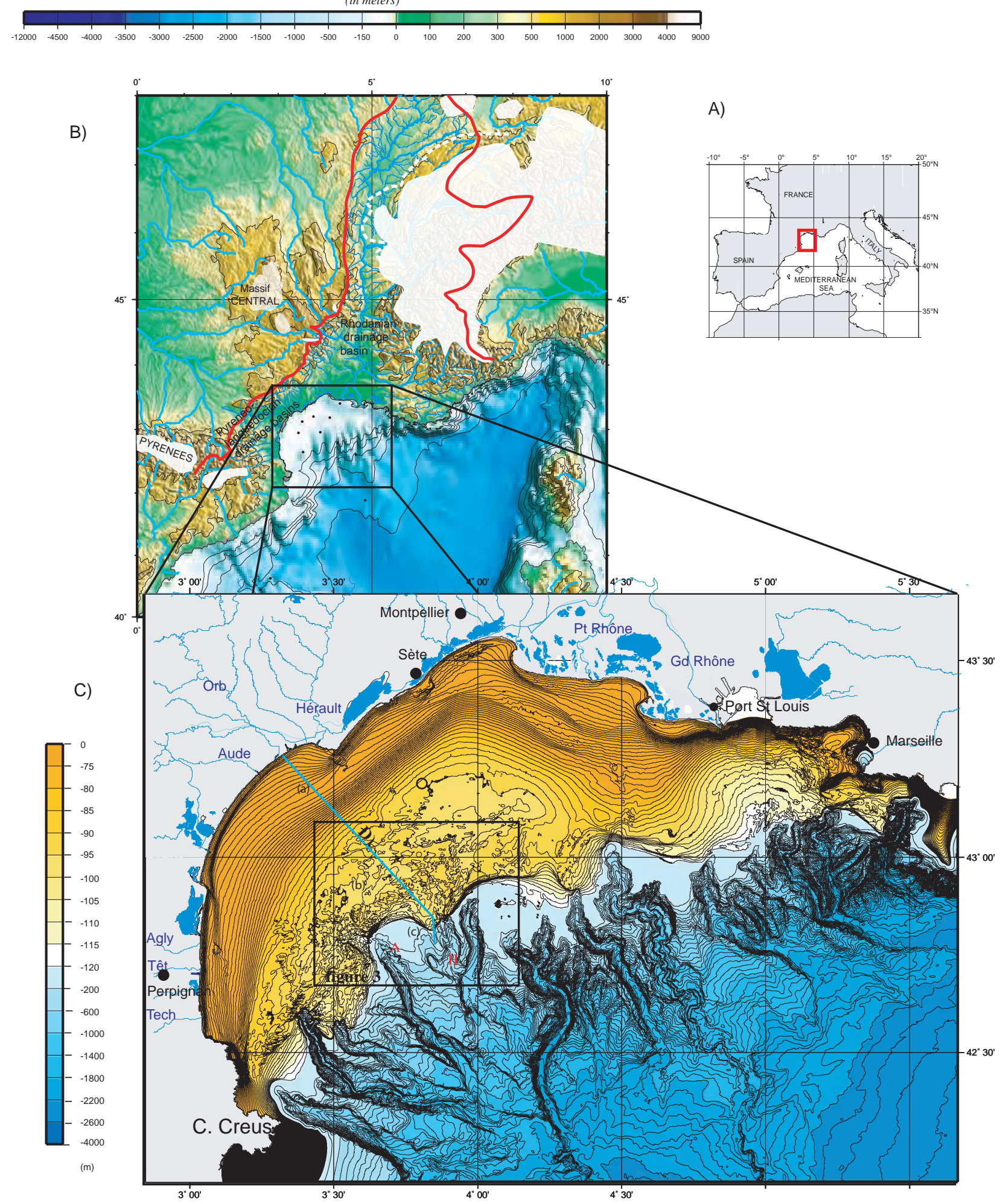

Present day

shoreline

and shoreface NW

$5 \mathrm{Km}$

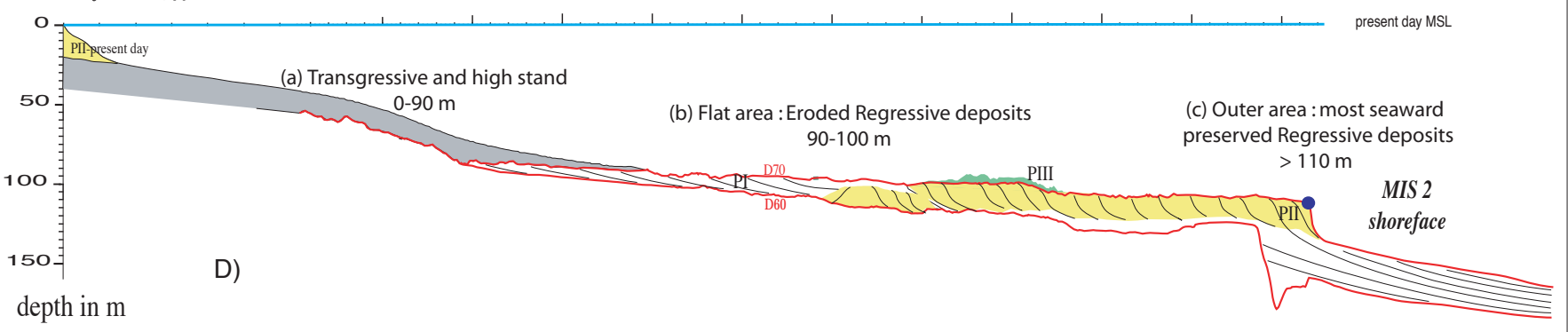




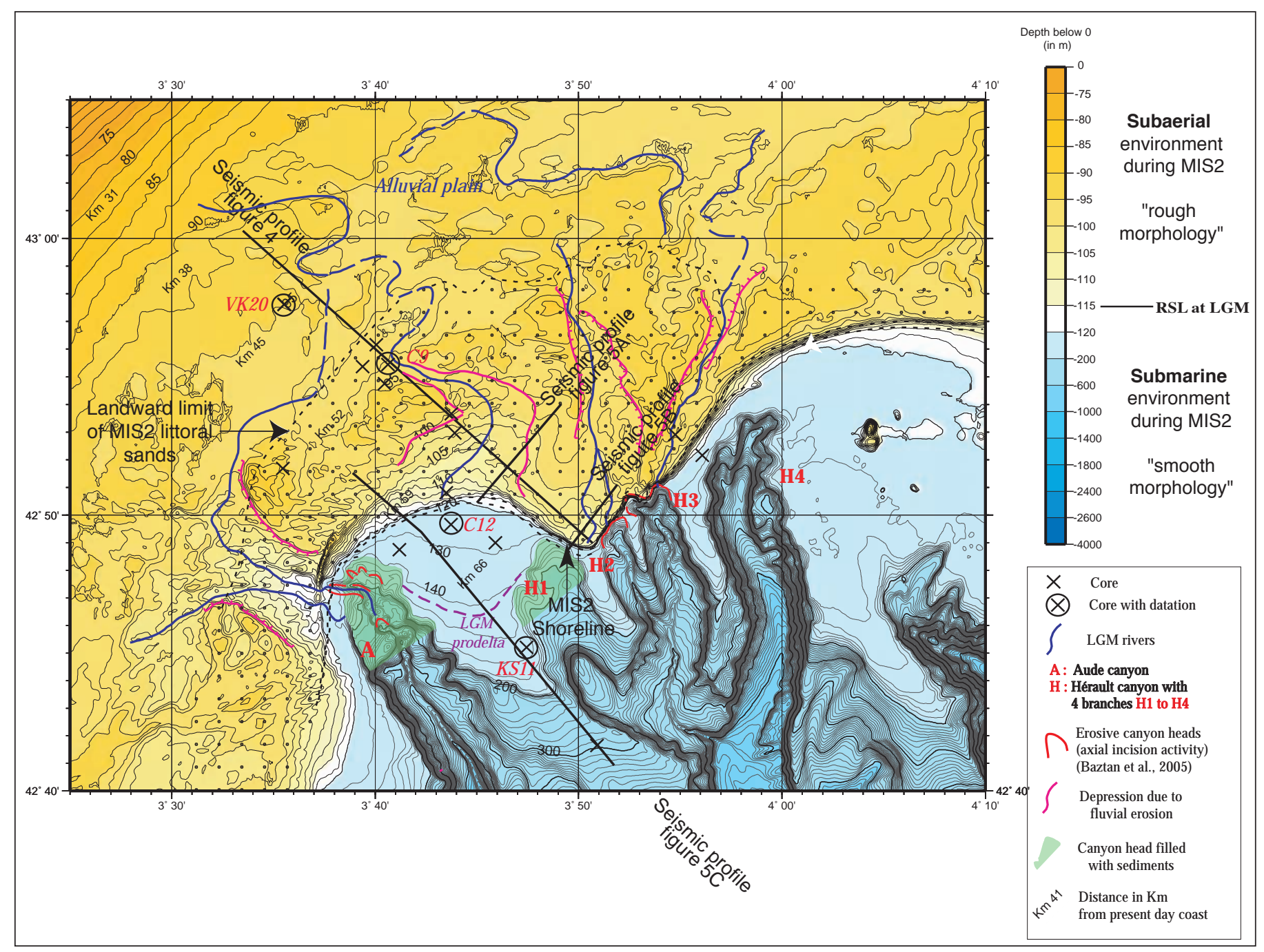

Rabineau et al., Figure 3 


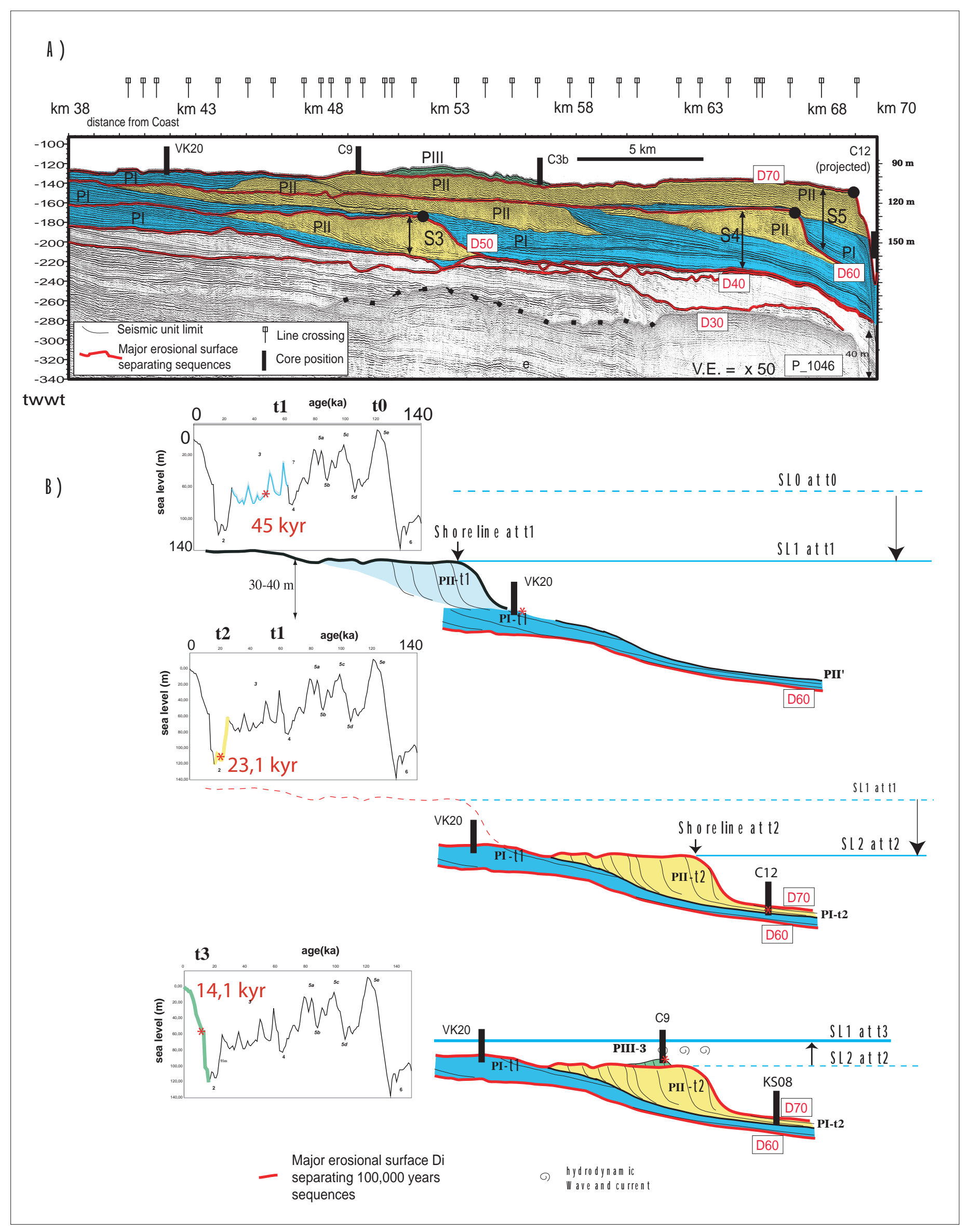




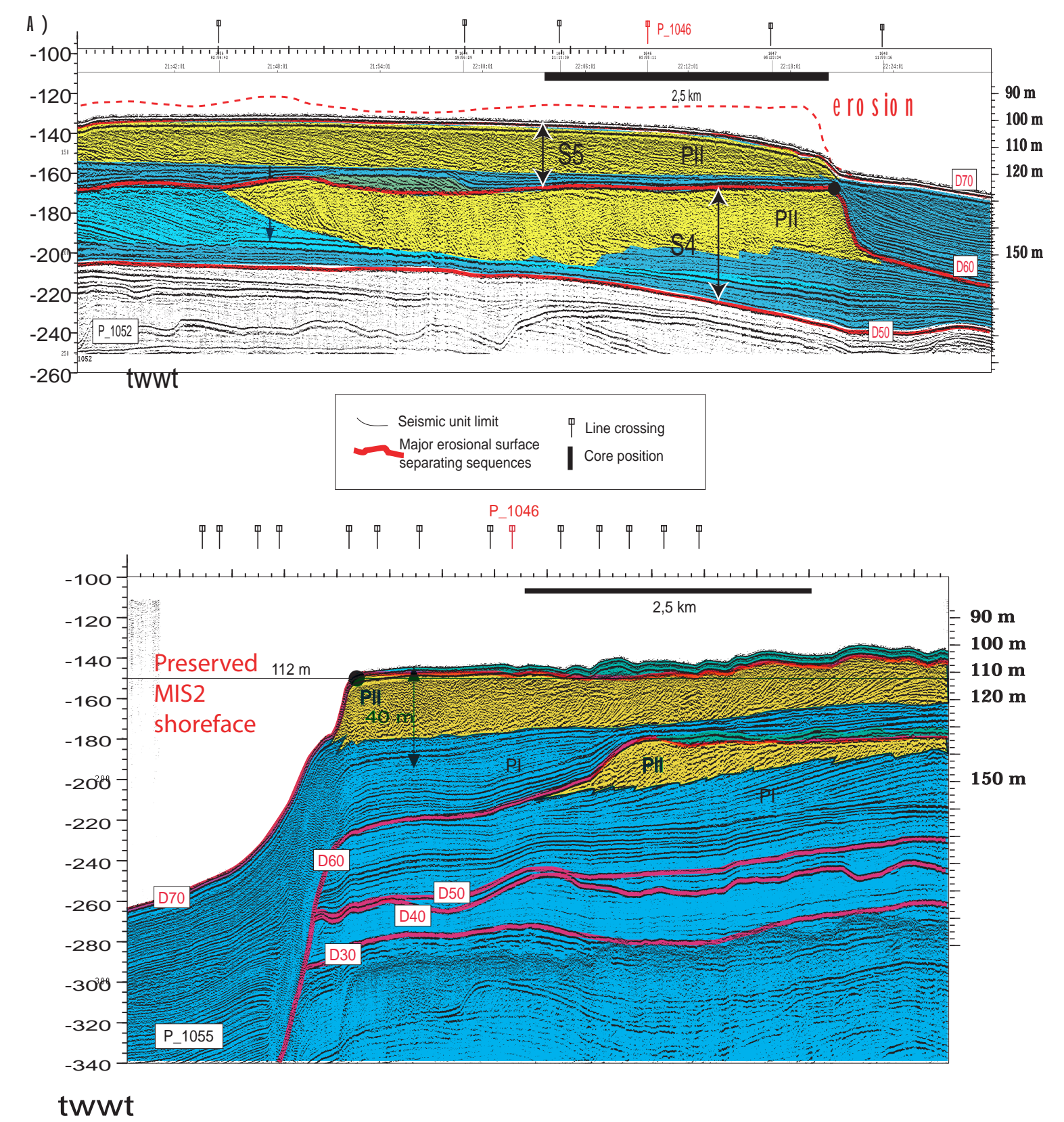

Rabineau et al. Figure 5 A) and B) 


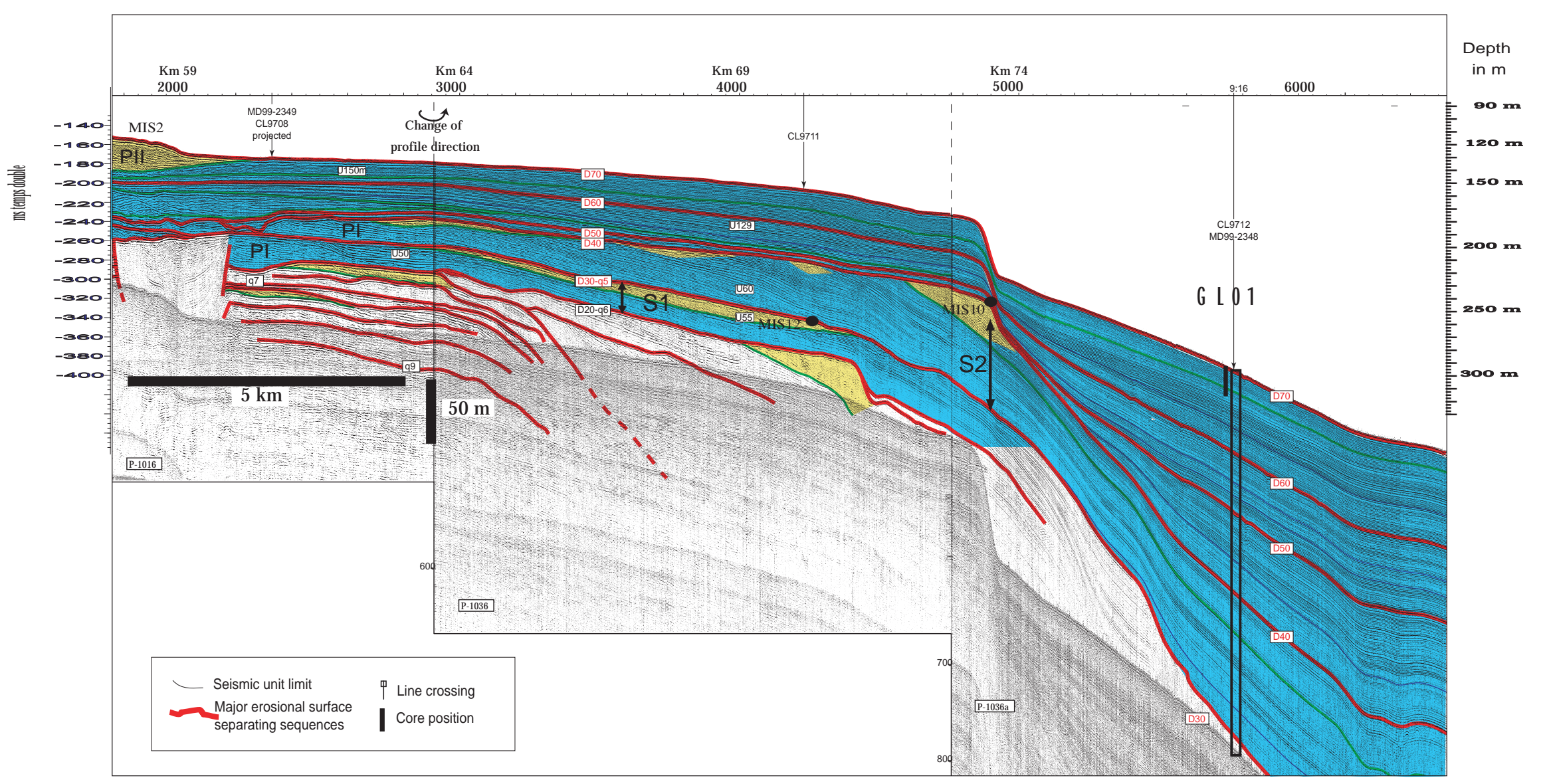

\section{Rabineau et al. Figure 5 (continued)}




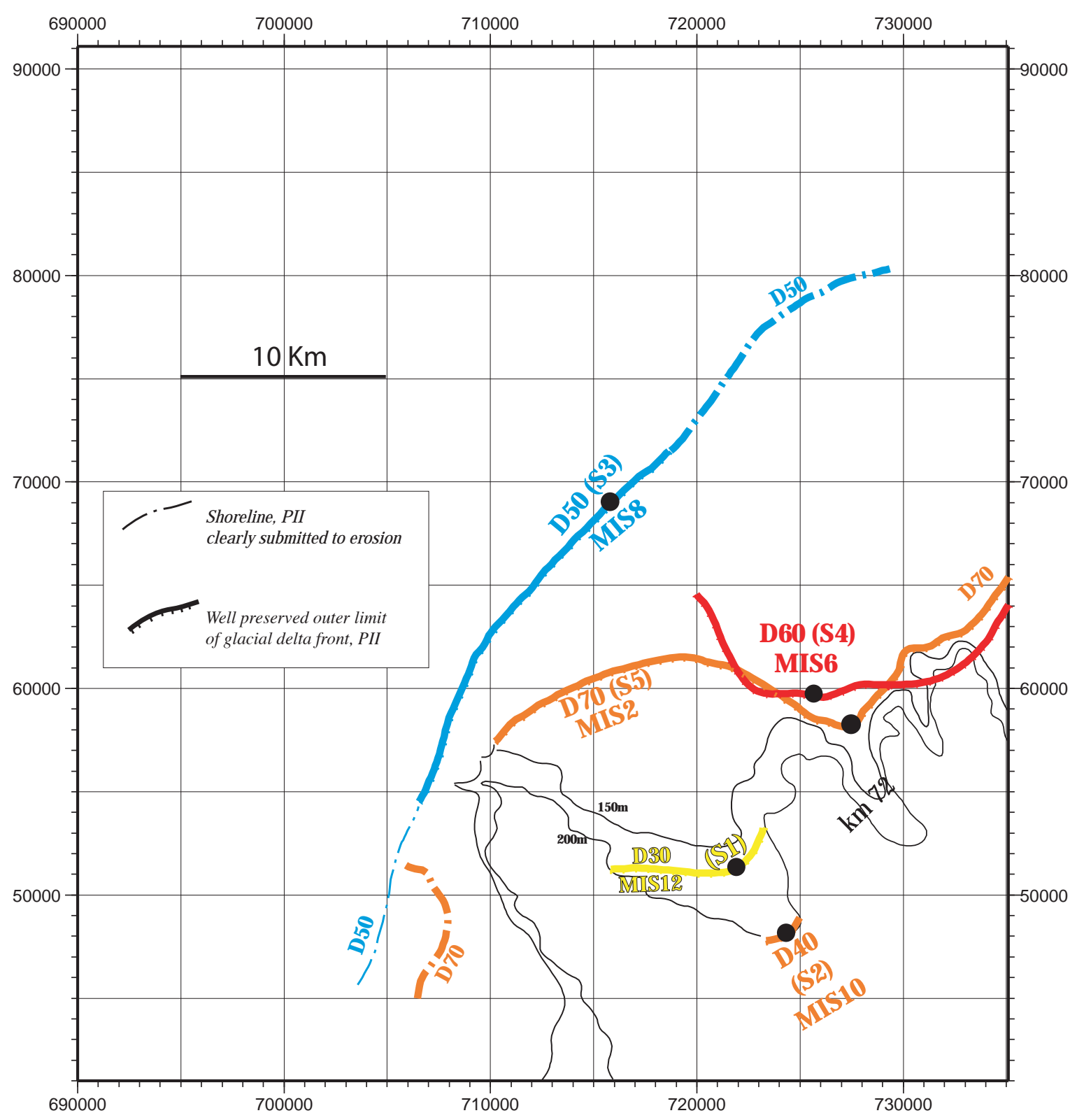

Rabineau et al., Figure 6 
NW

MIS 8.2-D50

shoreline

Distance from present day coast

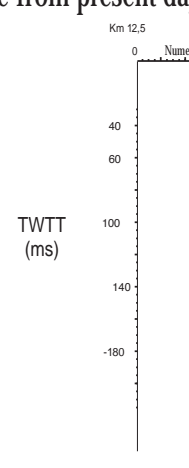

A)

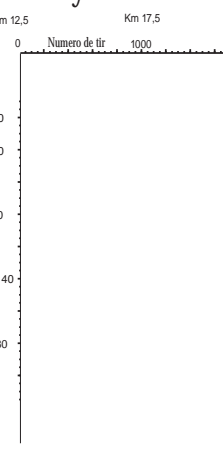

$\begin{array}{llllll}k m 22,5 & k m 27,5 & k m 32,5 & k m 37,5 & k m 42,5 & k m 47,5\end{array}$ ${ }_{7000}^{\mathrm{Km} 47.5}$ present day MSL

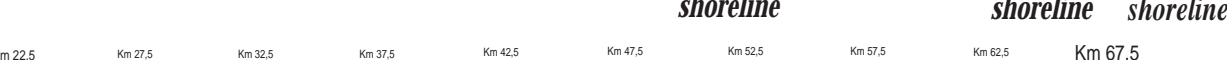

km $52.5 \quad \quad k m 575$

MIS 6.2-D60 LGM-D70

shoreline shoreline

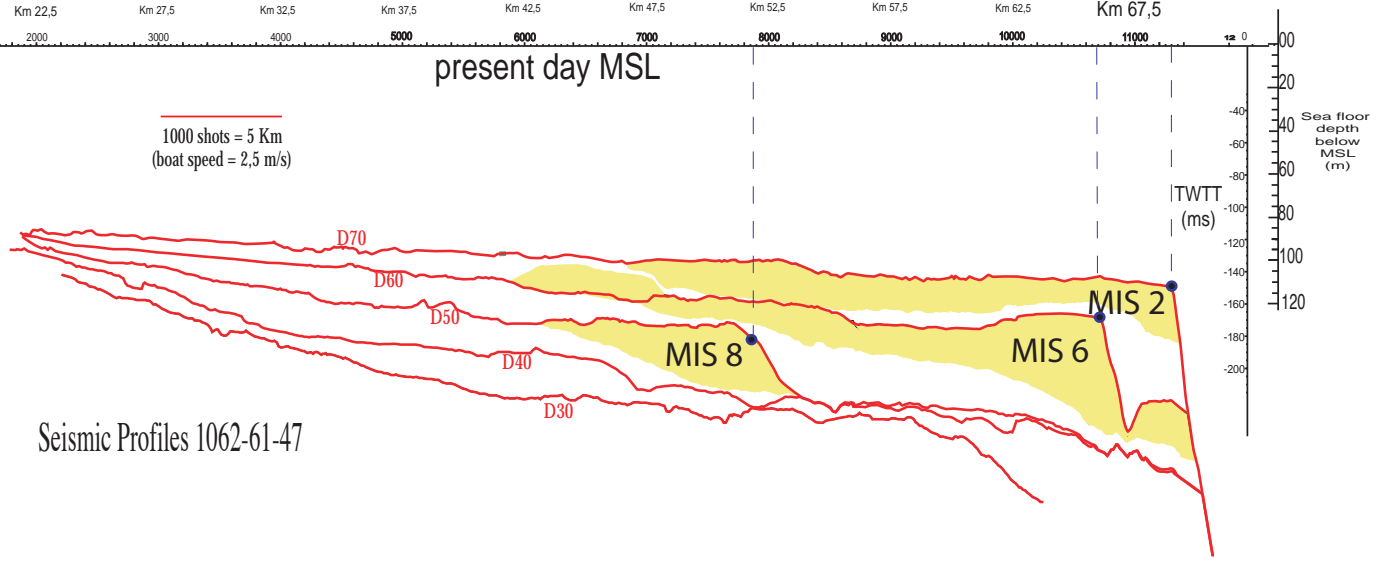

B)

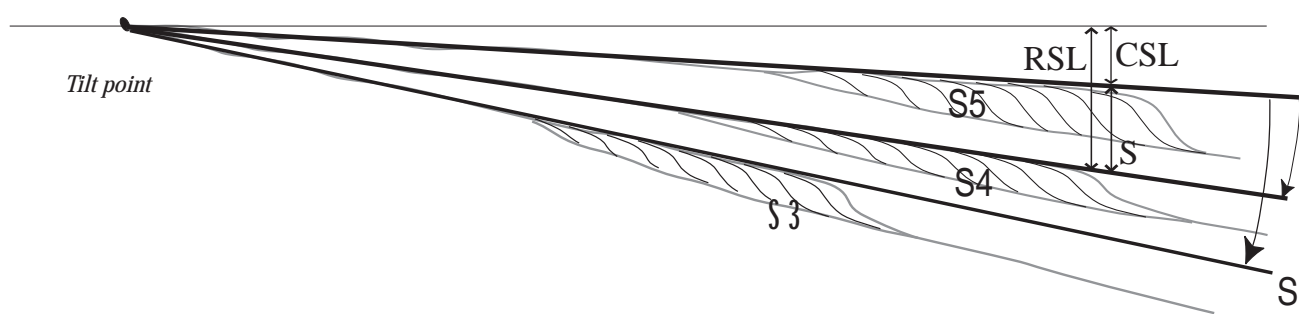

Reference level : present day sea level

Subsidence of S4 after deposition

Rabineau et al., Figure 7 


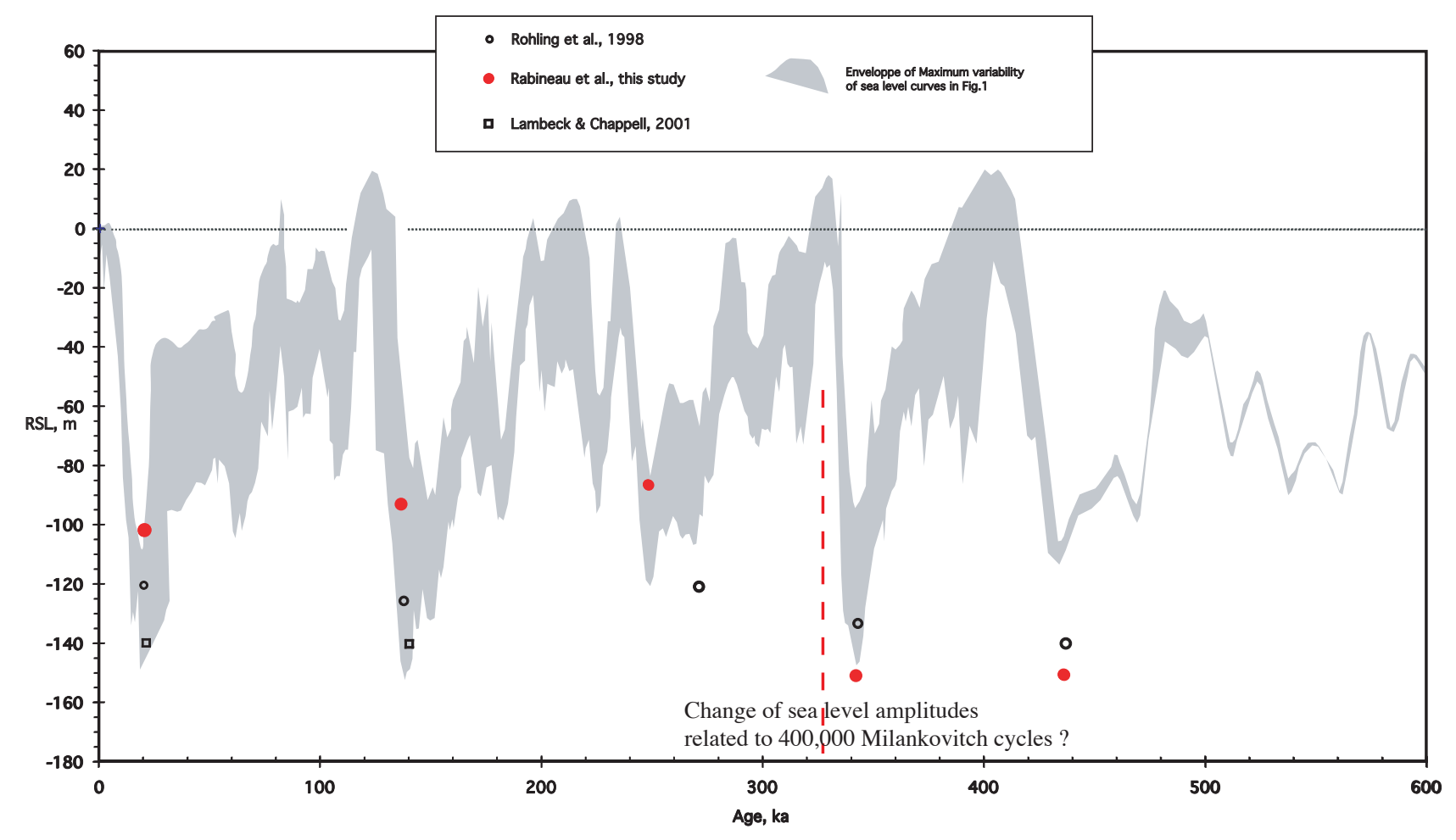

Rabineau et al., Figure 8 


\begin{tabular}{|c|c|c|c|c|c|c|}
\hline $\begin{array}{l}\text { Oxgen } \\
\text { Issotope } \\
\text { Stage }\end{array}$ & Age (kyr) & $\begin{array}{c}\text { Sea level Estimates } \\
\text { (meters below Prsent } \\
\text { SL) }\end{array}$ & $\begin{array}{c}\text { Ice equivalent } \\
\text { sea level } \\
\text { (meters below } \\
\text { PSL) }\end{array}$ & Authors & Location & Method \\
\hline \multirow[t]{17}{*}{ Stage 2.2} & $\begin{array}{l}18{ }^{14} \mathrm{C}-\mathrm{kyr} \\
(=21 \text { cal-kyr }\end{array}$ & & $\begin{array}{l}127 \\
163\end{array}$ & CLIMAP, 1981 & global & Climate models \\
\hline & & & 160 & Hughes et al. 1977 & global & Ice sheets \\
\hline & $\begin{array}{l}20 \text { cal-kyr } \\
21 \text { cal-kyr } \\
22 \text { cal-kyr } \\
30-19 \text { cal-kyr }\end{array}$ & & $\begin{array}{l}140 \\
123 \\
146 \\
130 \text { to } 140\end{array}$ & $\begin{array}{l}\text { Lambeck \& Chappell } 2001 \text { (Fig. 3b) } \\
\text { Lambeck et al., } 2002 \text { (fig. 11) }\end{array}$ & $\begin{array}{l}\text { Barbados, Bonaparte } \\
\text { Gulf, Sunda shelf, Tahiti, } \\
\text { Huon, Christchurch }\end{array}$ & $\begin{array}{l}\text { RSL records \& isostacy } \\
\text { RSL records \& isostacy }\end{array}$ \\
\hline & & & $125+/-5$ & Fleming et al., 1998 & & RSL records \& isostacy \\
\hline & & 105 & $\begin{array}{l}113.5-116.5 \\
<120 \mathrm{~m}\end{array}$ & $\begin{array}{l}\text { Peltier, 1994; } \\
\text { Peltier, 2002-QSR } \\
\text { Peltier, } 2002 \text { (reply) }\end{array}$ & Barbados & RSL records \& isostacy \\
\hline & & & $115-135$ & Milne et al., 2002 & $\begin{array}{l}\text { Barbados, Bonaparte } \\
\text { Gulf, Huon peninsula, } \\
\text { Tahiti }\end{array}$ & RSL records \& isostacy \\
\hline & & $\mathrm{RSL}=105-115$ & & Lambeck \& Bard, 2000 & Mediterranean Sea & RSL records \& isostacy \\
\hline & $18-17$ cal-kyr & RSL $=135-143$ & & Camoin et al., 2001 & $\begin{array}{l}\text { Moruroa, French } \\
\text { Polynesia }\end{array}$ & corals \\
\hline & $18-17$ cal-kyr & $110-115$ & & Camoin et al., 2004 & Indian Ocean, Mayotte & $\begin{array}{l}\text { Corals (Acropora + } \\
\text { Galasea+lithophyllum+ } \\
\text { hydrolithon) }\end{array}$ \\
\hline & 19 cal-kyr & 125 & & Fairbanks, 1989 & Barbados & \begin{tabular}{|l|} 
Drilled coral reefs, \\
Porites
\end{tabular} \\
\hline & 19 cal-kyr & 118 & & Bard et al., 1990 (nat) & Barbados & drilled Palmata coral \\
\hline & $\begin{array}{l}21 \text { cal-kyr } \\
19 \text { cal-kyr }\end{array}$ & $\begin{array}{l}116 \\
114 \\
\end{array}$ & & Hanebuth, 2000 & Sunda shelf & Sed cores \\
\hline & $\begin{array}{l}19-22 \mathrm{cal}-\mathrm{kyr} \\
19-22 \mathrm{cal}-\mathrm{kyr}\end{array}$ & $\begin{array}{l}121 \text { to } 125(+/-4) \\
\text { Discuss those results }\end{array}$ & -130 to -135 & $\begin{array}{l}\text { Yokoyama et al., } 2000 \\
\text { Yokoyama et al., 2001a } \\
\text { Shennan \& Milne, } 2003\end{array}$ & $\begin{array}{l}\text { Bonaparte Gulf } \\
\text { Bonaparte Gulf } \\
\text { Bonaparte Gulf }\end{array}$ & $\begin{array}{l}\text { RSL records \& isostacy } \\
\text { Cores analysis }\end{array}$ \\
\hline & $18{ }^{14} \mathrm{C}-\mathrm{kyr}$ & 130 & & Chappell \& Shackleton, 1986 & & \\
\hline & $20 \mathrm{cal}-\mathrm{kyr}$ & 120 & & Rohling, 1998 & Red Sea & Salinities in sed cores \\
\hline & & & & Siddall, 2003 & Red Sea & Hydro Model \\
\hline & & $\begin{array}{l}\text { Above } 130 \mathrm{~m} \\
\text { Above } 125 \mathrm{~m}\end{array}$ & & Ferland et al., 1995 & $\begin{array}{l}\text { Shelf Southeastern } \\
\text { Australia }\end{array}$ & Core analysis \\
\hline \multirow[t]{4}{*}{ Stage 6.2} & $135 \mathrm{kyr}$ & 125 & & Schackleton, 1987 & & Oxygen Isotopes \\
\hline & $135 \mathrm{kyr}$ & 130 & & Chappell \& Shackleton, 1986 & $\begin{array}{l}\text { Huon peninsula } \\
\text { Deep Pacific }\end{array}$ & $\begin{array}{l}\text { Uplifted sequences } \\
\text { Oxygen Isotopes }\end{array}$ \\
\hline & $135 \mathrm{kyr}$ & 125 & & Rohling, 1998 & Red Sea & Salinities in sed cores \\
\hline & & Above $130 \mathrm{~m}$ & & Ferland et al., 1995 & $\begin{array}{l}\text { Shelf Southeastern } \\
\text { Australia }\end{array}$ & Core analysis \\
\hline \multirow[t]{2}{*}{ Stage 8.2} & $270 \mathrm{kyr}$ & Above $120 \mathrm{~m}$ & & Rohling, 1998 & Red Sea & Salinities in sed cores \\
\hline & & Above $130 \mathrm{~m}$ & & Ferland et al., 1995 & $\begin{array}{l}\text { Shelf Southeastern } \\
\text { Australia }\end{array}$ & Core analysis \\
\hline $\begin{array}{l}\text { Stage } \\
10.2\end{array}$ & $340 \mathrm{kyr}$ & $122-134$ & & Rohling, 1998 & Red Sea & Salinities in sed cores \\
\hline $\begin{array}{l}\text { Stage } \\
12.2\end{array}$ & $440 \mathrm{kyr}$ & 139 & & Rohling, 1998 & Red Sea & Salinities in sed cores \\
\hline
\end{tabular}

Table 1 - Synthetis of published Sea level estimates 


\begin{tabular}{|c|c|c|c|c|c|c|c|c|c|c|c|c|c|}
\hline $\mathrm{D}_{\mathrm{i}}$ & MIS & $\begin{array}{c}\mathrm{D} \\
(\mathrm{km})\end{array}$ & $\begin{array}{l}\mathrm{W}_{\mathrm{e}} \\
\text { (ms) }\end{array}$ & $\begin{array}{c}\mathrm{W}_{\mathrm{s}} \\
(\mathrm{ms}) \\
\text { on Profile }\end{array}$ & $\begin{array}{l}W_{m} \\
(m)\end{array}$ & $\begin{array}{l}\mathrm{BU} \\
(\mathrm{m})\end{array}$ & $\begin{array}{l}\text { RSL } \\
(\mathrm{m})\end{array}$ & $\begin{array}{l}\text { RSL } \\
(\mathrm{m})\end{array}$ & $\begin{array}{c}\mathrm{R} \\
(\mathrm{m} / \mathrm{Ma})\end{array}$ & $\begin{array}{c}\text { A } \\
\text { (ka) }\end{array}$ & $\begin{array}{l}\mathrm{S} \\
(\mathrm{m})\end{array}$ & $\begin{array}{l}\text { CSL } \\
(\mathrm{m})\end{array}$ & $\begin{array}{c}\mathrm{CSL} \\
\mathrm{CSL}(\mathrm{m})\end{array}$ \\
\hline D70 & Stage 2.2 & 69 & 150 & $\begin{array}{l}150 \text { P1055 } \\
150-P 1047\end{array}$ & 112 & $0-10$ & $-102-112$ & $-107+/-5$ & $245+/-10$ & $20+/-5$ & $5+/-1$ & $(97)-\mathbf{1 0 7}+/-1$ & $-\mathbf{1 0 2}+/-6$ \\
\hline D60 & Stage 6.2 & 66 & $\begin{array}{l}157 \\
140\end{array}$ & $\begin{array}{l}168 \text { P1052 } \\
170 \text { P1046 }\end{array}$ & $\begin{array}{l}128 \\
128\end{array}$ & $0-10$ & $-118-128$ & $-123+/-5$ & $232+/-9$ & $135+/-5$ & $31+/-2$ & $(85)-97+/-2$ & $-92+/-7$ \\
\hline D50 & Stage 8.02 & 53 & 122 & 174-P1046 & 134 & $0-10$ & $-124-134$ & $-129+/-5$ & $175+/-7$ & $247,6+/-5$ & $43+/-3$ & $(81)-91+/-3$ & $-86+/-8$ \\
\hline $\mathrm{D} 40$ & Stage10.2 & 74 & 182 & $323-\mathrm{P} 1036$ & 246 & $0-10$ & $-236-246$ & $-241+/-5$ & $267+/-10$ & $341+/-5$ & $91+/-5$ & $(145)-155+/-5$ & $-150+/-9$ \\
\hline D30 & Stage 12.2 & 70 & 157 & $342-\mathrm{P} 1036$ & 262 & $0-10$ & $-252-262$ & $-257+/-5$ & $250+/-10$ & $434+/-5$ & $108+/-5$ & $(144)-154+/-5$ & $-149+/-10$ \\
\hline
\end{tabular}

Table 2 